\title{
The Value of Urban Nature in Terms of Providing Ecosystem Services Related to Health and Well-Being: An Empirical Comparative Pilot Study of Cities in Germany and the Czech Republic
}

\author{
Ralf-Uwe Syrbe ${ }^{1, *}$, Ina Neumann ${ }^{1}$, Karsten Grunewald ${ }^{1} \mathbb{D}$, Patrycia Brzoska ${ }^{1}$, Jiři Louda ${ }^{2} \mathbb{D}$, Birgit Kochan $^{1}$, \\ Jan Macháč ${ }^{2}$ D, Lenka Dubová ${ }^{2}$ D , Petr Meyer ${ }^{3}$, Jan Brabec ${ }^{2,4}$ (D) and Olaf Bastian ${ }^{5}$ \\ 1 Leibniz Institute of Ecological Urban and Regional Development, 01217 Dresden, Germany; \\ i.neumann@ioer.de (I.N.); k.grunewald@ioer.de (K.G.); p.brzoska@ioer.de (P.B.); b.kochan@ioer.de (B.K.) \\ 2 Institute for Economic and Environmental Policy, Faculty of Social and Economic Studies, \\ Jan Evangelista Purkyně University in Ústí nad Labem, 40096 Ústí nad Labem, Czech Republic; \\ louda@ieep.cz (J.L.); machac@ieep.cz (J.M.); dubova@ieep.cz (L.D.); brabec@e-academia.eu (J.B.) \\ 3 Department of Geology, Faculty of Science, Jan Evangelista Purkyně University in Ústí nad Labem, \\ 40096 Ústí nad Labem, Czech Republic; Petr.Meyer@ujep.cz \\ 4 Department of Social and Cultural Ecology, Faculty of Humanities, Charles University, \\ 11636 Prague 1, Czech Republic \\ check for \\ updates \\ Citation: Syrbe, R.-U.; Neumann, I.; \\ 5 Department of Environment and Municipal Utilities, State Capital of Dresden, 01001 Dresden, Germany; \\ olaf.bastian@web.de \\ * Correspondence: r.syrbe@ioer.de; Tel.: +49-351-4679219
} Grunewald, K.; Brzoska, P.; Louda, J.; Kochan, B.; Macháč, J.; Dubová, L.; Meyer, P.; Brabec, J.; et al. The Value of Urban Nature in Terms of Providing Ecosystem Services Related to Health and Well-Being: An Empirical Comparative Pilot Study of Cities in Germany and the Czech Republic. Land 2021, 10, 341. https://doi.org/10.3390/land10040341

Academic Editors: Ilaria Rodella and Massimiliano Mazzanti

Received: 15 February 2021

Accepted: 24 March 2021

Published: 27 March 2021

Publisher's Note: MDPI stays neutral with regard to jurisdictional claims in published maps and institutional affiliations.

Copyright: () 2021 by the authors. Licensee MDPI, Basel, Switzerland. This article is an open access article distributed under the terms and conditions of the Creative Commons Attribution (CC BY) license (https:// creativecommons.org/licenses/by/ $4.0 /)$.
Abstract: The quality of life in our cities critically depends on the intelligent planning and shaping of urban living space, in particular urban nature. By providing a wide range of ecosystem services (ES), urban nature essentially contributes to the well-being of city dwellers and plays a major role in avoiding common diseases through its positive impact on physical and mental health. Health is one of the most important factors underlying human welfare and is, thus, vital to sustainable development. The ES of urban green space provide other social-cultural functions alongside public health, for example by fostering environmental justice and citizenship participation. Thus, they should always be considered when searching for solutions to urban problems. The aim of this research was to determine the impact of green areas in three selected cities on the health and well-being of people by self-reporting of green areas' visitors. To this end, we posed the research question: which types and characteristics of urban green space are most appreciated by city dwellers? Based on our findings, we have drawn up recommendations for practices to promote better living conditions. We have also pinpointed obstacles to and opportunities for leisure time activities as well as ways of supporting the public health of citizens.

Keywords: environment assessment; recreation; urban green spaces; green infrastructure; urbanization; social interaction; interviews

\section{Introduction}

Since 2008, a majority of the world's population has been living in cities. Indeed, this share continues to grow: by $2030,60 \%$ of the global population is expected to be urbanized [1]. Data for 2018 show 77.3\% of Germans living in urban urbans, while in Czechia, the ratio is $73.8 \%$ [2]. The quality of life in cities depends not only on individual lifestyles but also on the planning and design of the urban fabric. This article contributes to recognizing the importance of specific green spaces as a factor of cultural urban development and makes recommendations that will benefit public health and the quality of urban living. Such urban development should enhance building structures and urban green spaces in 
such ways as to ensure better living conditions for residents by encouraging pleasurable leisure-time activities and effective healthcare [3].

The EU Biodiversity Strategy 2030 stipulates, among other things, that cities with over 20,000 inhabitants should develop green concepts by the year 2021 [4]. Two of the UN's Sustainable Development Goals are directly related to the topic, namely, SDG 11 to "Make cities and human settlements inclusive, safe, resilient and sustainable" and SDG 3 to "Ensure healthy lives and promote well-being for all at all ages". Target 3.4 of the latter goal is even more explicit: "By 2030, reduce by one third premature mortality from non-communicable diseases through prevention and treatment and promote mental health and well-being" [5].

If human well-being is the goal, prerequisite and result of sustainable development, we can certainly argue that health is the most important component of such well-being. In any case, healthcare is an essential human need, and the safeguarding of health is a decisive criterion for urban planning and a responsible local policy [6]. Urban nature with its ecosystems and biodiversity form a basis for health by providing services such as improved air quality and microclimate or recreational opportunities on green spaces $[7,8]$. Mankind enjoys a multitude of ES, including provisioning services such as food and medicines, regulation services such as crop pollination and climate remediation as well as cultural services. The general appreciation and enjoyment of urban green areas, water bodies or nearby trees constitute another class of ecosystem services (ES) [9]. All of these services are, in principle, public goods that benefit the entire population of the city, seemingly free of charge. Such ES are not just important for environmental reasons and to aid nature conservation but also fulfil social functions such as environmental justice and participation, especially in cities [10].

Nature in the city has a positive effect on mental and physical health, in particular promoting the early development of children [11]. Since a green living environment is often rated as pleasant, it increases subjective well-being [12-14]. Contact with nature may increase emotional resilience [15] and, by reducing aggression and crime rates, improve perceived safety and help to lower stress levels $[7,16,17]$. People who live in green surroundings also claim improvements in their state of health [18]. On the other hand, according to [19], the potential benefits to physical and mental health of urban green spaces depend not only on their quantity but also their quality (in this research, low-quality green spaces were associated with higher levels of self-reported poor health). A study by [20] showed that a higher tree canopy in cities can help prevent sleep disorders. For a systematic review of the effects on public health of urban green, see [21].

The supposed innate tendency of humans to seek connections with nature is called "biophilia" [22]. In architecture, Ref. [23] define biophilic design as a way of meeting this original need for close contact with the natural world. Such connections can even promote health [22]. For example, a window view onto green space has been found to strengthen the immune system and, thus, contribute to faster recovery from illness [24]. To provide maximum benefits, green spaces must not only be attractive and tempting but also be easily accessed by local residents. If people are able to enjoy a walk in nature while taking a short break from their busy urban lives, this will greatly boost their health and, thus, help society at large to save costs for the treatment of physical and mental disease [25-27].

In view of climate change and the ongoing process of urbanization, ES are becoming ever more important for cities and their residents. The limits imposed on free movement by the COVID-19 pandemic as well as the heatwaves experienced in Europe in recent summers have highlighted the importance of urban greenery for local residents, who have been increasingly making use of nearby green space [28-30]. Furthermore, the World Health Organization has warned of the pandemic's negative consequences on mental health, in particular the likelihood of higher levels of stress and anxiety as well as increased feelings of loneliness and depression [31].

Since mental well-being, in particular, can hardly be measured physiologically or directly observed, data can only be gathered through the self-assessment of affected peo- 
ple [32]. The value of ecosystems for human well-being as well as the health-promoting effect of the ES provided by urban green spaces are, thus, usually examined from the user perspective, primarily by means of surveys [18,33-38]. The "Nature Awareness Study" published every two years by the German government highlights the importance of nature and biological diversity for the local population. In 2017, when 2065 Germans were interviewed by means of computer-assisted face-to-face interviews, $81 \%$ agreed that biological diversity in nature promotes well-being and quality of life [39].

Against this background, the EU-funded INTEREG project BIDELIN ("The values of ecosystem services, biodiversity and green-blue infrastructure in cities using the examples of Dresden, Liberec and Děčín") examined a variety of ES and their appreciation by the population as well as in the administrations of three cities in the border region bridging Saxony (Germany, Dresden) and Bohemia (Czechia, Liberec and Děčín). Among other things, ways were sought to strengthen those cultural and regulating ES that contribute to human well-being by maintaining, designing and, where appropriate, enriching urban green spaces [40]. These health effects of urban nature, which were only a small part of the project task, are the focus of the current paper. We use the terms "urban green" and "urban green spaces" synonymously with "urban nature" to designate the very different forms of predominantly vegetation-rich areas found in cities. The expression "urban nature" is preferred when communicating with people from outside the field [41]. The term "green infrastructure" may also be applied to these areas of urban nature to aid understanding; the term "green-blue infrastructure" (as in the project title) explicitly includes water areas and wetlands. Here, green infrastructure is not merely a land-use category but also encompasses the planning idea of networking these areas, strengthening them functionally and developing them as a whole [42], even beyond the city, to boost ES. Indeed, this was one of our research goals.

The aim of the research was to determine the impact of green areas in three selected cities on the health and well-being of people by self-reporting of green areas' visitors. We wanted to describe the ways in which people value and appreciate urban green spaces and how they perceive their health-promoting effects. A special feature of the study is that we combined the survey on self-sensed health effects, feelings and ecosystem services in a comparison between cities of two European countries.

Rather than attempting to "measure" the impact on health and the local climate, the study focused on the subjective perceptions, motivations and evaluation of visitors to green spaces in terms of their enhanced health and well-being. Here, we intended to examine not just the impact of those areas where the survey took place but also the wider appreciation of urban green space types and a general reflection of their characteristics. Further, the study also investigated the motivation of interviewees to visit green space in the three cities in Germany and Czechia and the forms of recreation they undertook. By pinpointing such general preferences, the hope was to apply these values to other comparable elements of urban nature in order to map the health benefits of ES and derive recommendations for ways to improve urban green spaces. According to the cited literature, we studied and questioned several characteristics and relations that we consider as relevant for the function of green spaces for health and well-being to give recommendations for planning and management in order to strengthen these functions. We defined several research questions. (i) We wanted to find out if and how far people feel relaxed or stressed, positive or negative, alone or annoyed (and by what) during a visit in an urban green space $[37,43,44]$. (ii) We were interested if people are aware of the (scientifically reported) health effects [33]. (iii) We wanted to find whether there are relations between age groups and special types of greenery they prefer $[33,45]$. (iv) Finally, we focused on analysis of whether the proximity of green spaces affects cause for a visit $[18,46-48]$.

\section{Materials and Methods}

Surveys were carried out in one German and two Czech cities that are partners in the BIDELIN cooperation project, namely, Dresden, Děčín and Liberec, complemented by 
statistical analyses and mapping (Figure 1). The study was directed to people currently using green areas only, and the sample of respondents corresponds to this goal, as we aimed to make the sample representative of the population that utilizes urban greenery. Following the aim to ask people in several types of green space for their feelings and impressions, we selected at least two park areas with and without water elements, meadows with and without fruit trees and urban forests to carry out the surveys. Since it was not possible to find enough visitors in all the selected sites (more than 10 per city), we reduced the analysed answers to the sites with minimum 18 respondents, given in Table 1 and Figures 3, 5 and 7 .

To provide brief descriptions (see Figures 1-7).

Table 1. Demographic characteristics of the respondents.

\begin{tabular}{|c|c|c|c|c|c|}
\hline City & Dresden & Liberec & Děčín & $\begin{array}{l}\text { All } 3 \\
\text { Cities }\end{array}$ & $\begin{array}{c}\text { Chi-Square } \\
\text { Test ( } p \text {-Value) }\end{array}$ \\
\hline Respondents in total & 235 & 255 & 204 & 694 & \\
\hline Gender: male/female/diverse & $98 / 136 / 1$ & $139 / 116 /-$ & $117 / 87 /-$ & $354 / 339 / 1$ & 0.542 \\
\hline Respondents alone & $37 \%$ & $44 \%$ & $44 \%$ & $42 \%$ & 0.000 \\
\hline Respondents group 2-3 people & $42 \%$ & $47 \%$ & $51 \%$ & $46 \%$ & \\
\hline Respondents group >3 people & $20 \%$ & $9 \%$ & $5 \%$ & $12 \%$ & \\
\hline Respondents with dog & $11 \%$ & $30 \%$ & $40 \%$ & $27 \%$ & 0.000 \\
\hline Age range (youngest-oldest) & $11-89$ & $14-82$ & $14-88$ & $11-89$ & 0.000 \\
\hline Age group below $18(\%)$ & $7 \%$ & $6 \%$ & $4 \%$ & $6 \%$ & \\
\hline Age group 18 to 39 & $33 \%$ & $49 \%$ & $50 \%$ & $44 \%$ & \\
\hline Age group 40 to 69 & $40 \%$ & $32 \%$ & $39 \%$ & $37 \%$ & \\
\hline Age group above 69 & $20 \%$ & $14 \%$ & $7 \%$ & $14 \%$ & \\
\hline Education university/similar & $52 \%$ & $35 \%$ & $25 \%$ & $38 \%$ & 0.000 \\
\hline Education vocational training & $31 \%$ & $57 \%$ & $64 \%$ & $50 \%$ & \\
\hline Education without voc. training & $17 \%$ & $7 \%$ & $11 \%$ & $12 \%$ & \\
\hline
\end{tabular}

Dresden is the capital of the German federal state of Saxony. In 2018 (31 December) [49], its population was 554,649 . Over $60 \%$ of the urban precincts, which extend $328.3 \mathrm{~km}^{2}$, is made up of green space and forests such as the large Dresdener Heide. Visitors are also attracted by the wide meadows stretching along the banks of the River Elbe. Other typical characteristics of Dresden are the pleasant location of the city centre in a deep valley as well as the flood risk along the floodplain. Liberec is the capital of Liberec district. With 104,445 inhabitants (1 January 2019 [50]), it is the fifth biggest city in Czechia. Liberec is situated in a basin between the Jizera Mountains and the Jeschken Mountains, both over $1000 \mathrm{~m}$ high. About $40 \%$ of the $106.1 \mathrm{~km}^{2}$ municipal area is covered by forests. Close to the centre, the Harcov reservoir is the green heart of the city. The Czech city of Děčin has 48,809 inhabitants (1 January 2019 [50]). With a municipal area of $117.7 \mathrm{~km}^{2}$, it lies on the banks of the River Elbe, about 60 kilometres upstream from Dresden. Děčín is characterised by table mountains such as Kvaderberk, rock-climbing areas, a beautiful castle and amazing views alongside the relatively steep-sided Elbe river valley at the entrance to the world-famous Elbe sandstone mountains [40,51].

As previously mentioned, surveys were conducted to gather data on people's appreciation of green space. These oral interviews were held at various times of the day in different types of green areas in the three cities. The schedule was organized so that about one third of the interviews were conducted in the morning, one third in the afternoon and one third in the evening. The surveys took place from May to August 2018, mainly on working days. Potential interviewees were people either spending time in a green area or walking/cycling through it. Those questioned were asked whether this area was their destination or only part of their way. The willingness to take part in the survey was relatively high, with only about $10 \%$ of those asked refusing to take part. Therefore, there was no significant distortion of the target group. 


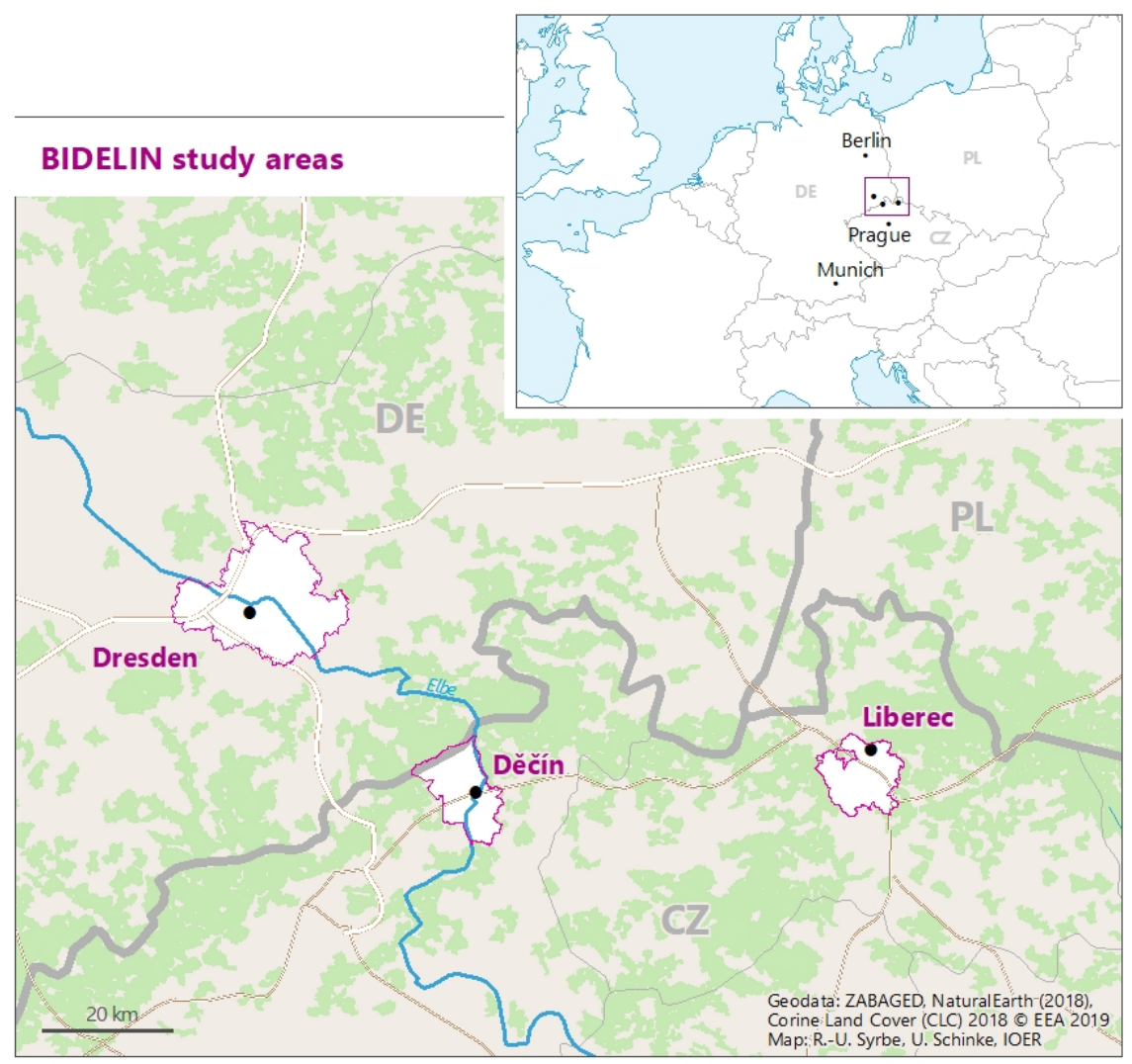

Figure 1. Locations of the surveyed areas in Germany and Czechia (source: authors' elaboration).

In Dresden, 235 people took part in the survey. One hundred and eleven interviews were conducted in public parks (see Figure 3: 53 in the Beutlerpark, 20 in the Blüherpark and 38 in the park Bürgerwiese). Another 63 people were interviewed along the main river in the district Loschwitz (Elbe meadow, see Figure 2), and 61 surveys were conducted in two urban forests (24 in the Albertpark, 37 in the Waldpark Blasewitz) (see Figure 3). An extended description of the research sites of the three cities is given in Appendix A.

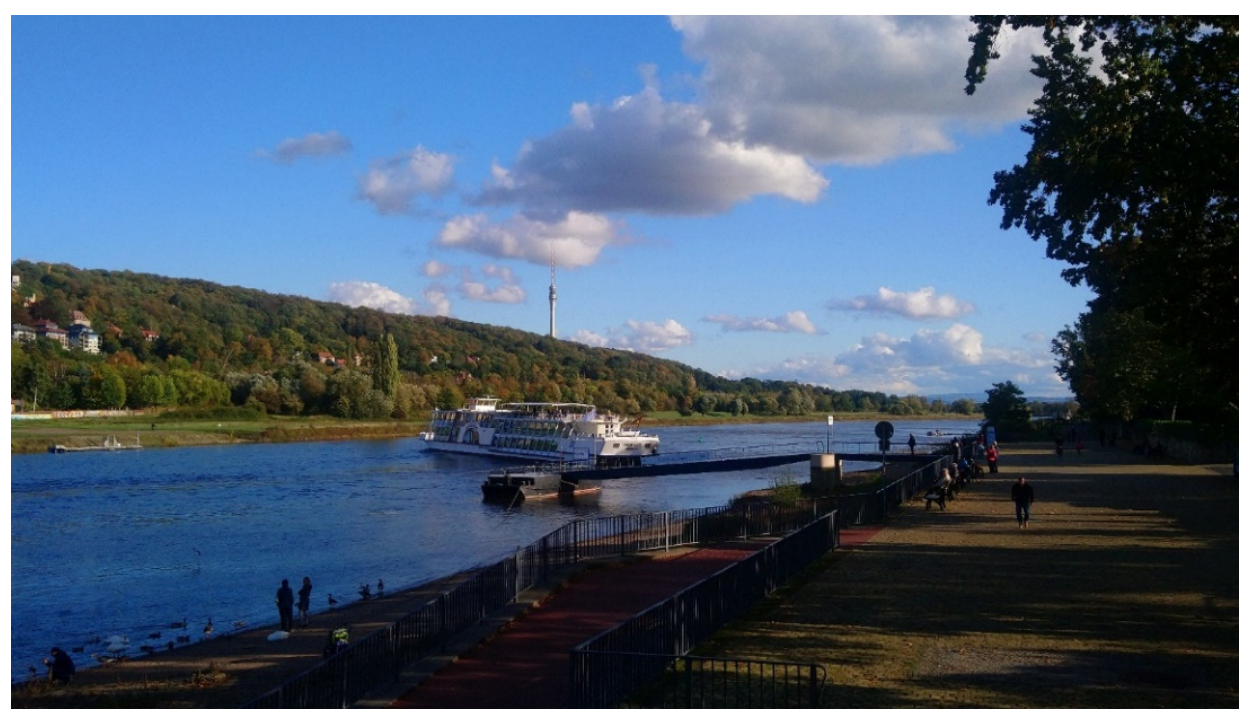

Figure 2. Dresden, view across the River Elbe to the survey location Loschwitz Elbe meadows (photo: R.-U. Syrbe). 


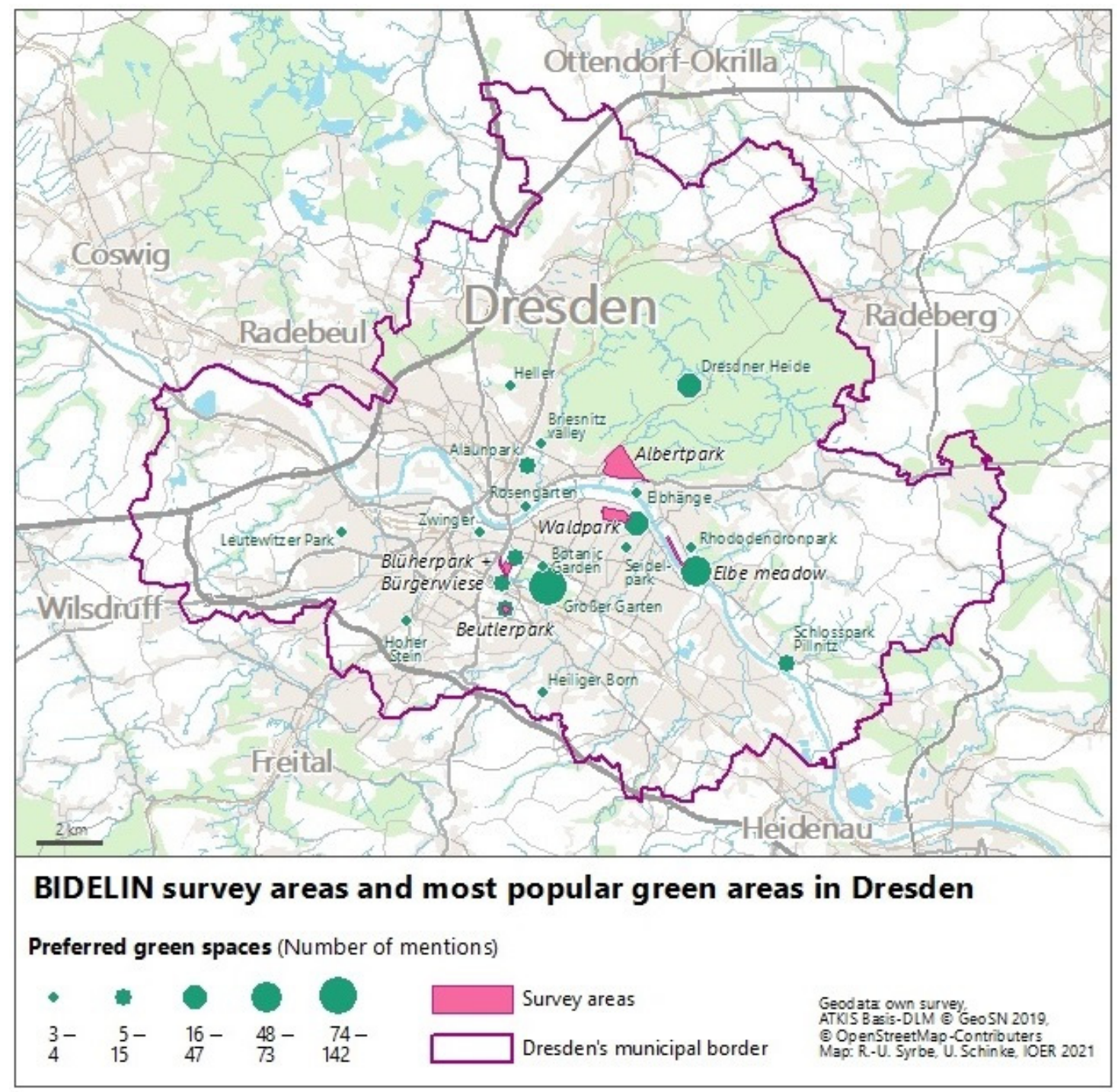

Figure 3. Survey areas in Dresden and the most popular green spaces (named at least three times in an open question) (source: authors' elaboration).

The surveys in Liberec recorded data from 255 people. The interviews, which were conducted in July 2018, addressed 27 people in the urban forest Liberecká výšina ("Liberec Hill”), 54 people in the park Budyšínská, 153 people around the reservoir Přehrada Harcov (Figure 4, foreground) as well as 21 people in the urban valley Kunratická Sídliště, (see Figure 5). An extended description of the research sites of the three cities is given in Appendix A. 


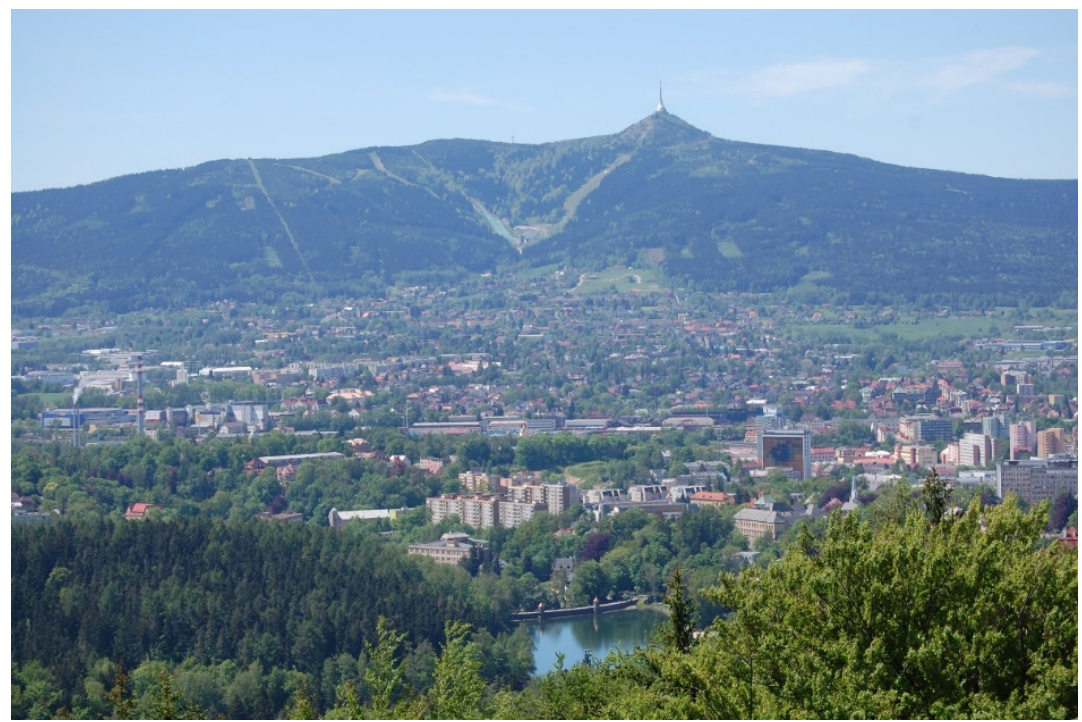

Figure 4. Liberec, Přehrada Harcov in the foreground and the landmark mountain Ještěd in the background (photo: K. Hrbková).

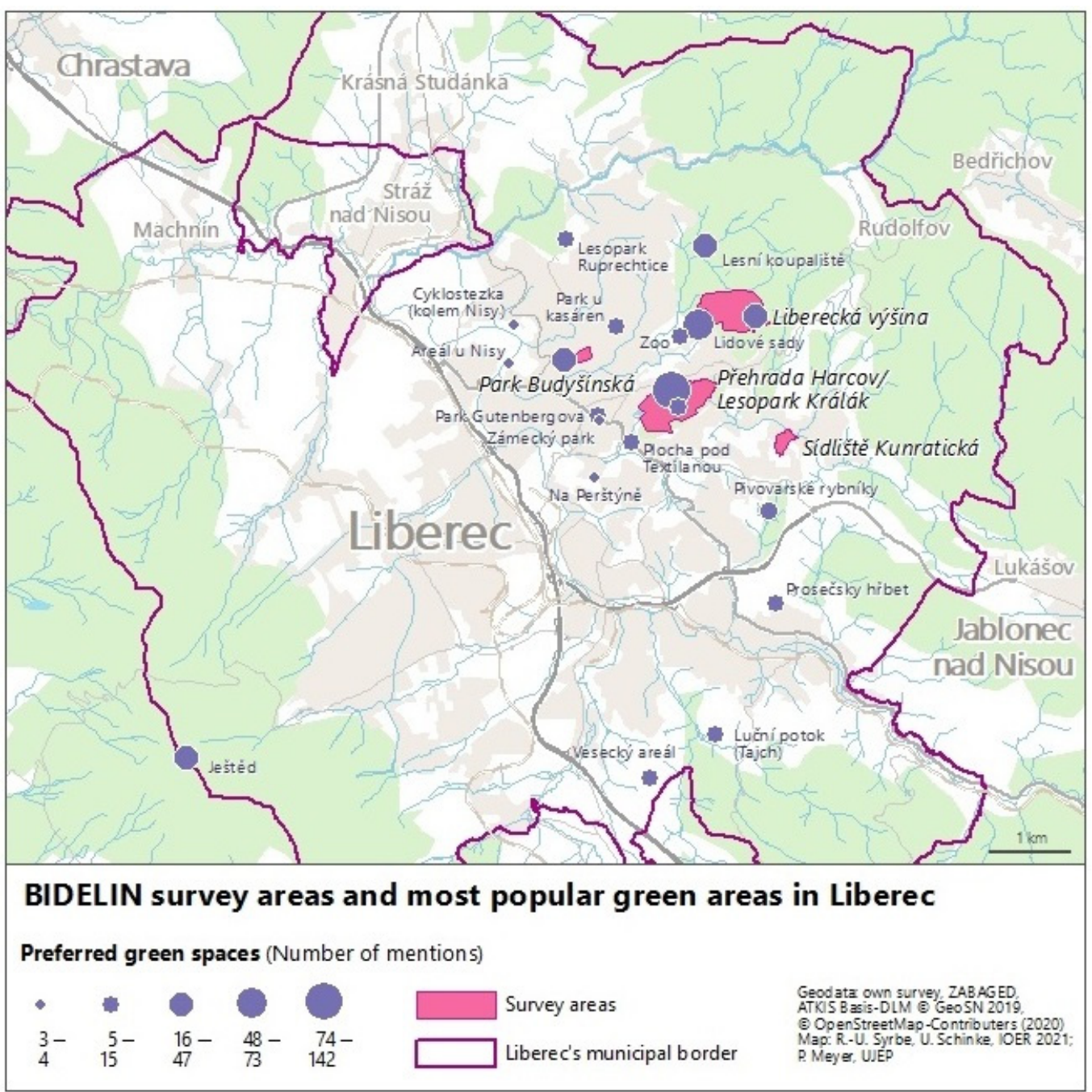

Figure 5. Survey areas in Liberec and the most popular green areas (named at least three times in an open question) (source: authors' elaboration). 
The surveys in Děčín recorded data from 204 people. The interviews, which were carried out in 2018, addressed 22 people in the Park u Máchovky, 80 people on the mountain Kvádrberk and at its foothill park (Stoličná hora), 84 people on the urban park Mariánská Louka and 18 people along the Elbe riverside meadow Stezka u Labe (Elbe cycle route) (see Figures 6 and 7). An extended description of the research sites of the three cities is given in Appendix A.

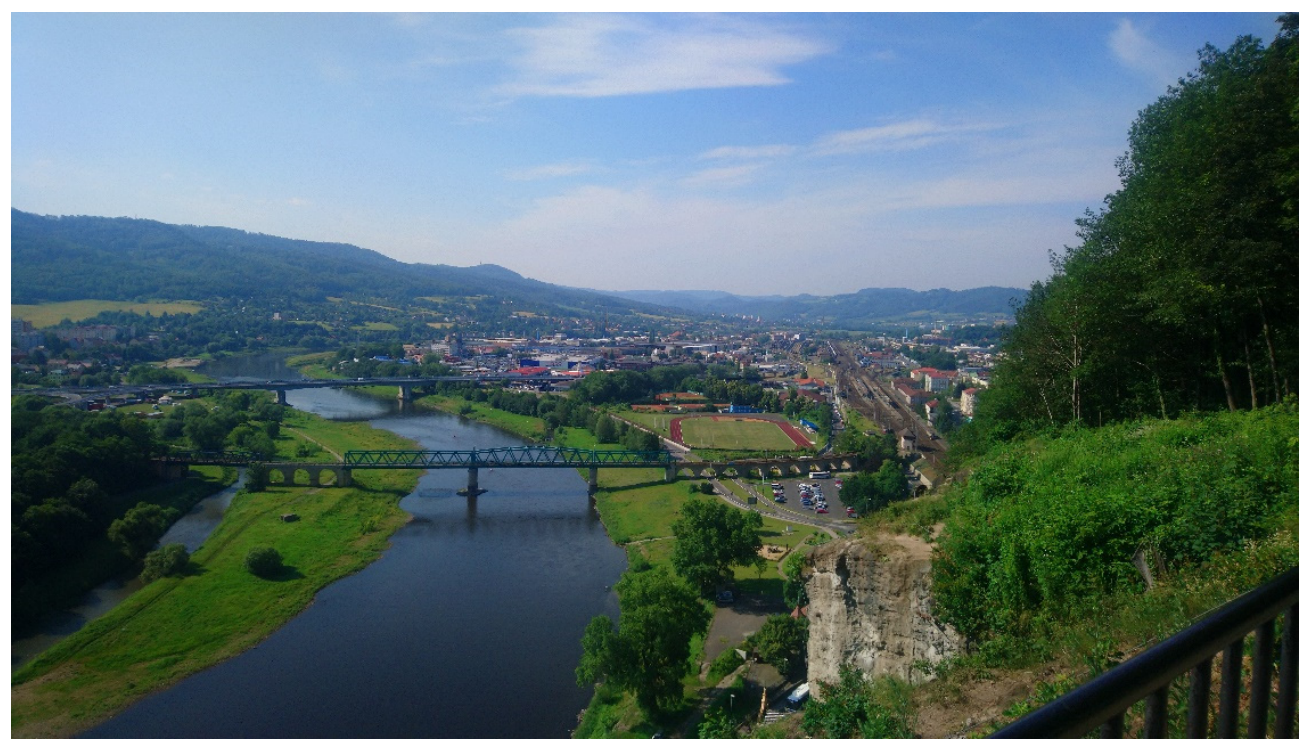

Figure 6. Děčín, view from the hilltop Pastýřská stěna to the city centre (right) and across the Elbe to the Stezka u Labe (left) (photo: R.-U. Syrbe).

Ideally, a sample close to 400 respondents is desirable to make sure the commonly used margin of error of $5 \%$ is satisfied. Our samples in each city fall short of this value; however, the resulting margins of error (Dresden-6.39\%; Liberec-6.14\%; Děčín-6.86\%) are not dramatically higher than the standard value. The reasons for the suboptimal number of respondents are as follows: (i) attempt to maintain a certain level of randomness in the sample selection instead of asking every person in the greenery; (ii) limited budget/number of days for the data collection, which unfortunately coincided with a heatwave, which reduced the number of people leaving their homes; (iii) attempt to cover different days of a week and different hours of a day.

The questionnaire was divided into three parts: The first was designed to gather information on the particular green space under consideration. The second part consisted of questions on the perception and appreciation of urban nature in general. The third part investigated the appreciation of ES and collected some demographic background information needed for the analysis (Appendix B). The questions were accompanied by a record of the location, time and rejection rate. The interviews lasted between 12 and $20 \mathrm{~min}$. Within the framework of this research, we also determined monetary values for the recreational performance of urban green spaces in the form of a willingness to pay (WTP) survey and a choice experiment. However, the results of the choice experiment will be the subject of a separate upcoming paper. In the two Czech cities, this questionnaire was combined with the choice experiment, making the survey even more complex. In Dresden, the questionnaire (as shown in Appendix B) and the choice experiment were conducted separately so as not to overwhelm the respondents. 


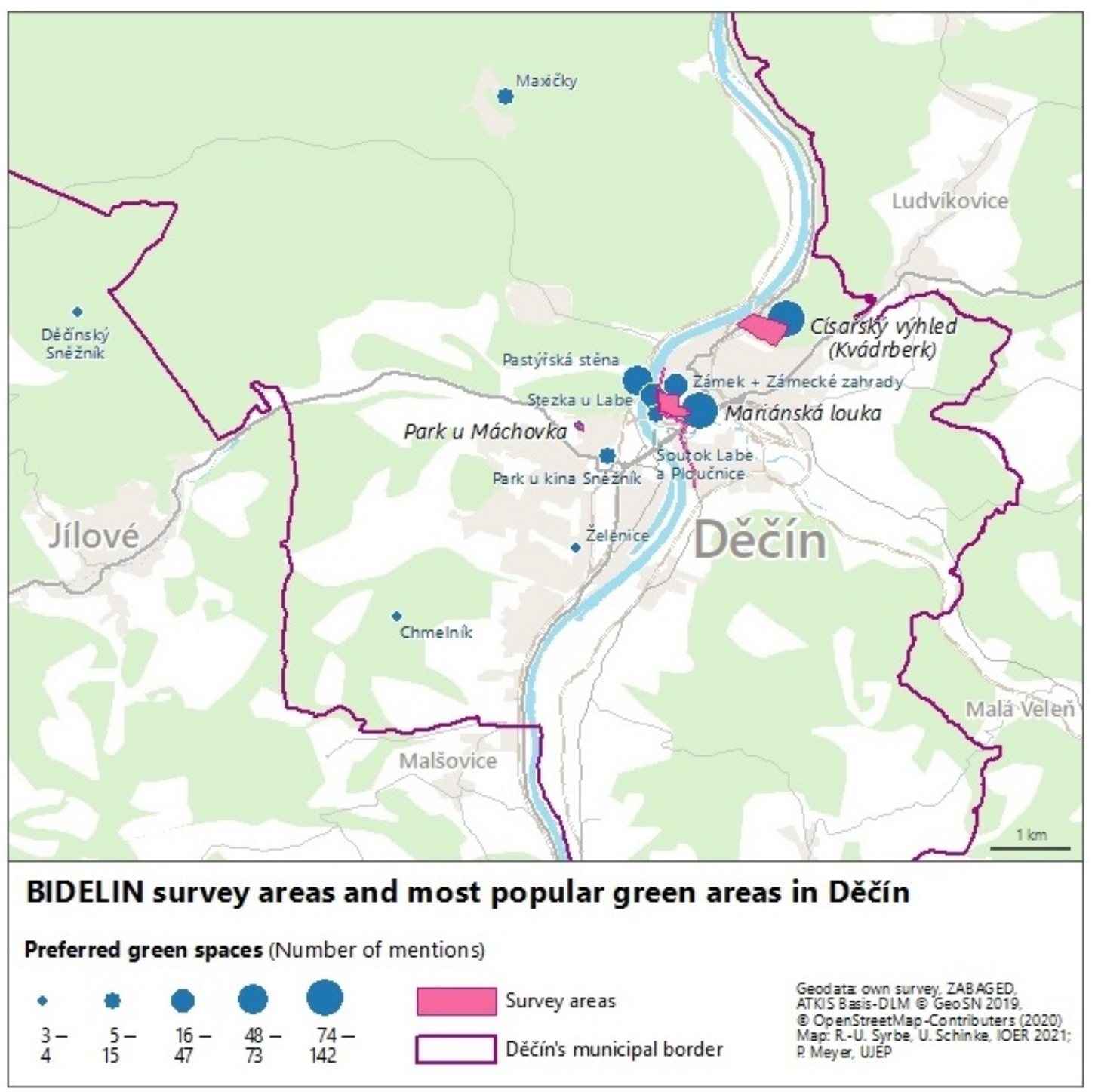

Figure 7. Survey areas in Děčín and the most popular green areas (named at least three times in an open question) (source: authors' elaboration).

Part 1 of the questionnaire referred to the area in which the survey took place. First, we asked where the person came from as well as how and for what purpose they were in the green area (in order to distinguish random passers-by from purposeful visitors). The next questions recorded the frequency and length of visits to allow the calculation of average visiting times per month. Then, we asked about the level of satisfaction with the respective area, classified from 1 (very good) to five (very bad). An open follow-up question gave the opportunity to name negative characteristics in order to capture some suggestions how to improve the green space. Question 6 recorded the motivations for the visit: respondents were asked to consider ten reasons for visiting the green area (Likert scale: "fully agree", "partly agree", "not at all"). This closed form of question was designed to capture secondary intentions that might otherwise have remained hidden as well as to compare the reasons for visiting different areas. The opening question "How do you feel after the visit—name a feeling spontaneously" was included to record potential health effects; simultaneously, this was intended to capture general welfare effects uninfluenced by other questions. The following closed question no. 8 supplied eight terms for likely feelings after the visit (see Appendix B), which could also be answered by the same Likert scale. These eight terms covered the most important benefits for health and social wellbeing described in the literature from "rested/relaxed" and "less lonely" to "unchanged" 
or even "stressed/worried". These last two answers were included to allow for the option of a negative impact of green space on respondents.

Part 2 of the questionnaire dealt with urban nature in general. First, the respondents were asked in an open question about the most popular natural and green spaces in the respective city in order to determine the most popular type of green space (park or other) without any suggestive specifications. The second question required the respondents to assign health effects to certain landscape elements in the form of a matrix. Here, the number of emotional terms was reduced to five (compared to eight in question no. 8) in order to encompass a relatively broad spectrum of 14 surface types that can be comparably identified both in all Czech and German cities and their databases without bias (Section 3.3). The visitors were additionally asked to mark three of the 14 landscape elements in which they felt most comfortable. Here, the aim was to create a popularity scale. Question 11 directly targeted ES, requiring the respondents to evaluate how importance urban services are to them using a three-item Likert scale. The $13 \mathrm{ES}$ were cultural and regulative services (Section 3.4), described in an easily understandable way and partly subdivided into separate aspects. In the third and final part of the survey, respondents were first asked to give their age to enable us to later assign their activities and the appreciation of certain types of green space to various age groups (see research questions). There was a similar aim behind the collection of information on education and gender. Question 19 on the number of accompanying persons was intended to address the research question on the social function of urban green spaces and to help estimate the total frequency of visits.

Following the on-site surveys, the questionnaires were encoded and the resulting data entered in the program IBM SPSS Statistics (Statistical Package for the Social Sciences) to quantitatively evaluate the responses. All qualitative and semi-quantitative relations have been analysed by charts and crosstabulation including Chi-square tests, metric connections between several characteristics were analysed using charts and tested by Spearman-Rho correlation on 0.01 percent level (for more details see below).

Additionally, to find out whether socio-demographic characteristics have an effect on perceived feelings about the green space where the interview took place, a series of logit models were estimated. A binary dependent variable indicated whether respondents reported that they felt a particular feeling at the given place (e.g., relaxed, comfortable). Independent variables were represented by age, gender, education and income. A statistical significance would indicate that a particular group of people described by the abovementioned variables may be more/less likely to report their feelings in a certain way.

\section{Results}

\subsection{Socio-Demographic Characteristics and General Health Effects}

In total, we collected valid answers from 235 respondents in Dresden, 255 in Liberec and 204 in Děčín. To keep the interviews short, we only asked for some essential sociodemographic information, which is shown in Table 1. It is apparent that with the exception of gender, the samples in the studied cities are statistically different from each other.

First, we asked for a spontaneous statement about the interviewees' current feeling before they were confronted with a list of possible terms. The most frequent answers were (in this order): relaxed, (very) well, rested, recovered and several other positive feelings (in Czechia also "comfortable"). Less than $3 \%$ of interviewees reported negative feelings; in the Czech cities, the proportion was just 1\%. Then, we surveyed the reaction to a selection of pre-defined terms. Here, the proportionate responses are given in Table 2. Of the 235 respondents in Dresden, $82 \%$ stated that they felt more relaxed, $69 \%$ were happier, $69 \%$ physically better, $54 \%$ more energetic, $45 \%$ better able to concentrate and only $16 \%$ no longer lonely after spending time in a green space. The results are similar in Liberec and in Děčín (where merely the proportions of respondents expressing positive feelings are somewhat lower) (Table 2). In general, it can be seen that very few respondents strongly agreed with the neutral statement "I feel unchanged" (only $11 \%$ on average) and practically no one with the statement "I feel stressed and loaded" (below $1 \%$ everywhere). 
Table 2. Feelings while visiting urban green space (total agreement).

\begin{tabular}{lcccc}
\hline Reported Feelings & Dresden (\%) & Liberec (\%) & Děčín (\%) & All 3 Cities (\%) \\
\hline Recovered/relaxed & 82 & 73 & 68 & 74 \\
Satisfied/happy & 69 & 68 & 71 & 69 \\
Comfortable & 69 & 60 & 46 & 59 \\
Energetic & 54 & 52 & 49 & 52 \\
Able to concentrate & 45 & 47 & 39 & 44 \\
No longer lonely & 16 & 34 & 29 & 26 \\
Unchanged & 6 & 13 & 15 & 11 \\
Stressed/worried & 1 & 1 & 1 & 1 \\
\hline
\end{tabular}

As indicated above, a series of logit models were estimated that explored relationships between reported feelings and socio-demographic characteristics. The results are shown in Table 3.

Table 3. Dependence of reported feelings on selected socio-demographic characteristics.

\begin{tabular}{|c|c|c|c|c|c|c|}
\hline \multicolumn{7}{|c|}{ Dresden } \\
\hline Variable & Relaxed & Comfortable & Energetic & Able to Concentrate & Happy & No Longer Lonely \\
\hline \multirow{2}{*}{ Constant } & $1.78842^{* * *}$ & 0.499168 & -0.334002 & -0.382995 & 0.650108 & $-2.78781^{* * *}$ \\
\hline & $(0.556785)$ & $(0.430410)$ & $(0.403739)$ & $(0.392793)$ & $(0.431711)$ & $(0.734263)$ \\
\hline \multirow{2}{*}{ Age } & -0.0114717 & 0.00418126 & 0.00543950 & -0.00890324 & -0.00445033 & 0.0133889 \\
\hline & $(0.0106164)$ & $(0.00845908)$ & $(0.00812922)$ & $(0.00786056)$ & $(0.00867046)$ & (0.0106299) \\
\hline \multirow{2}{*}{ High school } & 0.344000 & 0.339615 & 0.312153 & $1.08062^{* *}$ & 0.408403 & 0.557839 \\
\hline & $(0.664502)$ & $(0.496234)$ & $(0.471635)$ & $(0.478547)$ & $(0.492674)$ & $(0.730684)$ \\
\hline \multirow{2}{*}{ University } & 0.410596 & 0.0922761 & -0.0904652 & 0.503731 & 0.442762 & 0.552023 \\
\hline & $(0.580000)$ & $(0.452929)$ & $(0.438717)$ & $(0.437496)$ & $(0.475897)$ & $(0.719624)$ \\
\hline \multirow{2}{*}{ Female } & 0.0186244 & 0.0533364 & 0.364923 & 0.0966142 & 0.106450 & -0.0348459 \\
\hline & $(0.362439)$ & $(0.300013)$ & $(0.274743)$ & $(0.272902)$ & $(0.299127)$ & $(0.361402)$ \\
\hline McFadden's pseudo R2 & 0.006404 & 0.005624 & 0.015147 & 0.020641 & 0.003715 & 0.023576 \\
\hline Log likelihood & -105.7773 & -139.2034 & -156.7502 & -156.1988 & -140.3313 & -99.23397 \\
\hline Correctly predicted (\%) & 82.7 & 70.6 & 57.1 & 57.1 & 70.1 & 84 \\
\hline Observations & 231 & 231 & 231 & 231 & 231 & 231 \\
\hline \multicolumn{7}{|c|}{ Liberec } \\
\hline Variable & Relaxed & Comfortable & Energetic & Able to Concentrate & Happy & No Longer Lonely \\
\hline \multirow{2}{*}{ Constant } & -0.0687115 & $-0.805985^{* *}$ & $-0.987163^{* *}$ & -0.474714 & 0.350487 & $-0.966437^{* *}$ \\
\hline & $(0.410130)$ & $(0.407412)$ & $(0.420432)$ & $(0.396132)$ & $(0.403354)$ & $(0.433155)$ \\
\hline \multirow{2}{*}{ Age } & $0.0209528^{* *}$ & 0.0108161 & $0.0162000 *$ & 0.000966957 & 0.00449724 & 0.00140426 \\
\hline & $(0.00953240)$ & $(0.00818113)$ & $(0.00844728)$ & $(0.00791051)$ & $(0.00850471)$ & $(0.00841853)$ \\
\hline High school & 0.489223 & 0.0715048 & -0.442526 & 0.00315083 & -0.404934 & 0.0827686 \\
\hline \multirow{2}{*}{ University } & $\begin{array}{c}(0.539007) \\
0.327976\end{array}$ & $\begin{array}{l}(0.459582) \\
0.0771198\end{array}$ & $\begin{array}{c}(0.478936) \\
-0.961547\end{array}$ * & $\begin{array}{l}(0.468387) \\
0.0778281\end{array}$ & $\begin{array}{l}(0.481215) \\
-0572473\end{array}$ & $\begin{array}{c}(0.527107) \\
0.00417654\end{array}$ \\
\hline & $(0.590341)$ & $(0.514185)$ & $(0.523801)$ & $(0.512055)$ & $(0.528830)$ & $(0.564800)$ \\
\hline \multirow{2}{*}{ Female } & -0.0548315 & 0.441044 & $0.822388^{* * *}$ & 0.376286 & 0.266066 & 0.142362 \\
\hline & $(0.320720)$ & $(0.284272)$ & $(0.279906)$ & $(0.270616)$ & $(0.301391)$ & $(0.283326)$ \\
\hline \multirow{2}{*}{$\begin{array}{l}\text { Between minimum and } \\
\text { medium wage }\end{array}$} & -0.0836923 & $0.742719^{*}$ & 0.729148 & 0.186750 & 0.733336 & 0.281732 \\
\hline & $(0.513463)$ & $(0.434053)$ & 0.445054 & $(0.440338)$ & $(0.456152)$ & $(0.494357)$ \\
\hline \multirow{2}{*}{ Above average wage } & -0.515835 & 0.203614 & 0.387929 & -0.93005 & 0.347336 & -1.21278 \\
\hline & $(0.686394)$ & $(0.607728)$ & $(0.626696)$ & $(0.629558)$ & $(0.614978)$ & $(0.767911)$ \\
\hline \multirow{2}{*}{$\begin{array}{l}\text { McFadden's pseudo R2 } \\
\text { Log likelihood }\end{array}$} & 0.027650 & 0.043874 & 0.066240 & 0.027020 & 0.016532 & 0.028435 \\
\hline & -149.1204 & -167.1828 & -166.1190 & -172.1405 & -158.2637 & -157.7866 \\
\hline \multirow{2}{*}{$\begin{array}{l}\text { Correctly predicted (\%) } \\
\text { Observations }\end{array}$} & 71.6 & 60.3 & 63.4 & 61.5 & 67.7 & 67.3 \\
\hline & 257 & 257 & 257 & 257 & 257 & 257 \\
\hline \multicolumn{7}{|c|}{ Děčín } \\
\hline Variable & Relaxed & Comfortable & Energetic & Able to Concentrate & Happy & No Longer Lonely \\
\hline \multirow{2}{*}{ Constant } & $1.22615^{*}$ & -0.870024 & -0.530890 & -0.416794 & 0.174484 & -0.635367 \\
\hline & $(0.668247)$ & $(0.535445)$ & $(0.525944)$ & $(0.525453)$ & $(0.576467)$ & $(0.597146)$ \\
\hline & -0.00538729 & 0.00947003 & -0.00125631 & 0.00218336 & 0.00597420 & -0.00427937 \\
\hline Age & 0.00953704 & $(0.00836446)$ & $(0.00838933)$ & $(0.00822896)$ & $(0.00934025)$ & $(0.00870605)$ \\
\hline & -0.373833 & -0.325162 & 0.551440 & -0.229922 & 0.141755 & 0.414881 \\
\hline High school & $(0.678637)$ & $(0.530791)$ & $(0.549791)$ & $(0.532950)$ & $(0.536583)$ & $(0.538883)$ \\
\hline University & -0.858114 & -0.743742 & 0.177059 & -0.434156 & 0.131584 & -0.122109 \\
\hline University & $(0.698699)$ & $(0.592304)$ & $(0.594682)$ & $(0.590217)$ & $(0.583415)$ & $(0.616409)$ \\
\hline & $0.857446^{* *}$ & $0.648680 * *$ & 0.308902 & 0.258077 & 0.548346 & 0.0496108 \\
\hline $\begin{array}{l}\text { Female } \\
\text {. }\end{array}$ & $(0.347608)$ & $(0.317868)$ & $(0.311049)$ & $(0.312975)$ & $(0.342600)$ & $(0.340057)$ \\
\hline Between minimum and & -0.269727 & 0.348680 & 0.00776474 & 0.113191 & 0.118211 & -0.557427 \\
\hline medium wage & $(0.386220)$ & $(0.351170)$ & $(0.337611)$ & $(0.340272)$ & $(0.382572)$ & $(0.363217)$ \\
\hline Above average wage & -0.607995 & 0.738624 & -0.152879 & -0.820091 & -0.447340 & 0.000783053 \\
\hline Above average wage & $(0.534040)$ & $(0.515990)$ & $(0.518085)$ & $(0.596645)$ & $(0.536347)$ & $(0.552755)$ \\
\hline McFadden's pseudo R2 & 0.058159 & 0.028734 & 0.012665 & 0.022261 & 0.026187 & 0.021989 \\
\hline Log likelihood & -115.9186 & -130.9604 & -134.1261 & -127.9623 & -116.7586 & -118.0740 \\
\hline Correctly predicted (\%) & 69.9 & 57.7 & 57.7 & 61.7 & 69.9 & 69.4 \\
\hline Observations & 196 & 196 & 196 & 196 & 196 & 196 \\
\hline
\end{tabular}

Significance levels: ${ }^{*} 0.1,{ }^{* *} 0.05,{ }^{* * *} 0.01$. 
The results show that there are very few statistically significant relationships between reported feelings and socio-demographic characteristics. It turns out that mainly women may be more likely to attach feelings to the place they visit. Women in Děčín more often stated that they felt relaxed and comfortable than their male counterparts, while women in Liberec felt more energetic. Additionally, older people in Liberec were more likely to feel relaxed and energetic in a green place. However, it seems that there are no significant differences in reporting feelings among socio-economic groups. This is an important piece of knowledge for decision makers, who may be more confident in results of various surveys and do not need to worry about bias that may result from the sample of respondents.

While respondents were asked about eight different feelings, only six are reported in Table 3. The reason for this is insufficient variability in the dependent variable, as very few people reported they felt unchanged or stressed (see Table 2). In a similar fashion, income variables were unavailable in Germany, and therefore, they were not included in the models for Dresden.

\subsection{Individual Appreciation of Single Areas}

The respondents could choose between the Likert values "fully agree" (3), "partly agree" (2) or "disagree" (1) for the feelings listed in Table 2. By summing and averaging the values for positive feelings, we derived a general mark for the appreciation of the different green areas. These marks are listed in Table 4 and used to rank the green areas within the cities. To provide a control, we compared the neutral (unchanged) and negative (stressed/loaded) feelings. However, this did not result in a different ranking. The Likert scores are included in the column "Positive feelings reported $(3=$ max. $)$ ", the other data in Table 4 are the number of respondents in each area, the percentage of people that see the respective green area as final destination, the others were just on the way "from A to B" (given as "Pathway"), the satisfaction mark for the respective green area and the calculated visiting time using the frequency and the duration of stay per month. To provide a control, we compared the neutral (unchanged) and negative (stressed/loaded) feelings. However, this did not result in a different ranking.

Table 4. Survey findings on urban green areas as final destination vs. pathway, satisfaction level and average duration of visits per month (green spaces in each city ranked by positive feelings of respondents).

\begin{tabular}{|c|c|c|c|c|c|c|}
\hline $\begin{array}{c}\text { City ( }\left(^{1-3} \text { See Footer) }\right. \\
\text { and Survey Area }\end{array}$ & $\begin{array}{c}\text { No. of } \\
\text { Respondents }\end{array}$ & $\begin{array}{c}\text { Positive Feelings } \\
\text { Reported } \\
\text { (3= max.) }\end{array}$ & $\begin{array}{c}\text { Final } \\
\text { Destination } \\
(\%)\end{array}$ & $\begin{array}{l}\text { Path } \\
\text { Way } \\
(\%)\end{array}$ & $\begin{array}{c}\text { Satisfaction } \\
(1=v . \text { High to } \\
5=v . \text { Low })\end{array}$ & $\begin{array}{c}\text { Visiting Time } \\
\text { (Hours/Month } \\
\text { pers.) }\end{array}$ \\
\hline Waldpark $^{1}$ & 37 & 2.52 & 92 & 8 & 1.62 & $7: 42$ \\
\hline Bürgerwiese 1 & 38 & 2.49 & 66 & 34 & 1.74 & $8: 06$ \\
\hline $\begin{array}{l}\text { Loschwitz E. } \\
\text { meadows } 1\end{array}$ & 63 & 2.45 & 48 & 52 & 2.14 & $9: 13$ \\
\hline Beutlerpark ${ }^{1}$ & 53 & 2.39 & 91 & 9 & 1.58 & $6: 34$ \\
\hline Albertpark ${ }^{1}$ & 24 & 2.24 & 79 & 21 & 2.08 & $16: 15$ \\
\hline Blüherpark ${ }^{1}$ & 20 & 2.18 & 70 & 30 & 1.80 & $10: 09$ \\
\hline Přehrada Harcov ${ }^{2}$ & 153 & 2.47 & 71 & 29 & 2.56 & $11: 38$ \\
\hline Kunratická-Sídliště 2 & 21 & 2.38 & 48 & 52 & 2.52 & $14: 16$ \\
\hline Liberecká výšina 2 & 27 & 2.33 & 56 & 44 & 1.63 & $4: 29$ \\
\hline Park Budyšínská ${ }^{2}$ & 54 & 2.25 & 52 & 48 & 2.06 & $17: 20$ \\
\hline Stezka u Labe ${ }^{3}$ & 18 & 2.48 & 56 & 44 & 1.72 & $7: 36$ \\
\hline Park u Máchovky ${ }^{3}$ & 22 & 2.47 & 68 & 32 & 3.23 & $8: 03$ \\
\hline Kvádrberk ${ }^{3}$ & 80 & 2.33 & 84 & 16 & 2.13 & $12: 29$ \\
\hline Mariánská louka ${ }^{3}$ & 84 & 2.27 & 85 & 15 & 2.01 & $13: 35$ \\
\hline
\end{tabular}

${ }^{1}$ Dresden, ${ }^{2}$ Liberec, ${ }^{3}$ Děčín.

We applied a correlation analysis to learn about the relationships among the chosen health effects and between the effects and the distance to a given area as well as its size (for statistical numbers see Appendix C). First, we found that all health effects are significantly connected with each other at the 0.01 significance level; this applies simultaneously for all three cities with no exception. However, second, there is hardly a relation to the distance 
to the area or its size. For Dresden and Děčín, we did not find any significant correlation, only in Liberec there is a slight correlation between size and "rested, relaxed" as well as "more able to concentrate, more awake" at 0.05 level (see Appendix C). Only the feeling "physically more comfortable" is at 0.01 level correlated to the size of area here. For this analysis, we work only with five reported feelings (from 8), as we did it in case of Table 2.

Various reasons were given for visiting green spaces: In all three cities, the four reasons "enjoy fresh air", "enjoy some peach or relax", "observe and experience nature" and "do something for my health" were (in this order) similarly most chosen by more than $85 \%$ of the respondents. The following reasons were "to talk and be with other people" (Dresden $77 \%$ Liberec $71 \%$, Děčín $72 \%$ ) and "be active in sports" (45, 58, 65\% cities in same order). The other given reasons were chosen less frequently, depending on situation of the visitors. "get from A to B" $(54,60,51 \%$, respectively), "enable my children to play outdoors" $(36,43$, $26 \%$, respectively) and "walk my dog" (38, 32, $12 \%$, respectively). The reasons have been statistically compared with the age groups (see Appendix C): The reason to do something for health is significantly connected to age groups between 0.45 (Dresden), 0.29 (Liberec) and 0.25 (Děčín), i.e., the older the people, the more important was the reason healthcare for the visit. Additionally, the reason to be active in sports is correlated with age groups, but not in the same way. Surprisingly, older people in Dresden want to be more active in sports, while in the Czech cities, this applies to the younger age groups. The social effect to talk and be with other people is not connected to age in Dresden, but there is a significant correlation in Děćín, where mainly younger people want to have contacts in the urban green. A similar tendency is applicable for Liberec, but not significant there. The other reasons such as "to enjoy some peace and relax" have no statistical connection to the age groups.

The answer "get from A to B" was very different among the cities, depending on whether the site was a final destination or rather a pathway to some other location, which was the case for 20 to $37 \%$ of interviewees in the three cities. For example, more than half of respondents in the Dresden's Elbe meadows (52\%) and Liberec's Kunratická-Sídliš̌̌ $(52 \%)$ indicated that they were heading to another location. In contrast, the following green areas were final destinations for the majority of those questioned: Beutlerpark (91\%) and Waldpark (92\%) in Dresden, Přehrada Harcov in Liberec (71\%), Kvadrberg (84\%) and Mariánská louka (85\%) in Děčín. These areas also got very good marks for satisfaction, with the exception of Prrehrada Harcov, which was ranked worst for satisfaction in Liberec and Park u Máchovky in Děčín (Table 4).

Apart from their use as pathways/road connections, clearly there are various other reasons to visit green spaces. For example, the preferred uses of Dresden's Loschwitz Elbe meadow is to get from A to B, to do something for one's health and to work out; the city's Waldpark, on the other hand, is mainly used to enjoy fresh air, to find peace and quiet and to observe nature; Dresden's Albertpark and Beutlerpark are seen as attractive outdoor places to let children play; the Beutlerpark is also used for socialising with other people, while the Blüherpark is seen as the best place to walk a dog. In Děčín, Park u Máchovky is a social meeting place, Kvaderberg is visited for health and fitness reasons as well as to find peace and enjoy nature, while Mariánská louka is primarily used to let children play.

We asked for the length of the recent stay in the locations and learned for Dresden that people spend most time in Waldpark, followed by Beutlerpark and Albertpark, while Bürgerwiese was the area with the shortest stay. Statistically (see Appendix C), there is no significant correlation. The same applies to Liberec, where Park Budyšínská as smallest area and Přehrada Harcov as the largest were visited for the longest time, and no significant correlation exists. On the contrary, in Děčín, there is a significant correlation between size of an area and average length of stay, which is $r=0.247$ (Spearman-Rho at 0.01 significance level). The two larger areas Kvadrberg and Mariánská louka had the longest average visiting time, while people stay for shorter periods in the other two areas (or just pass through). 
When comparing the frequency of visits to the distance from origin of the trip, there were significant correlations at 0.01 level for all cities: we found negative correlation values -0.42 (Dresden), -0.44 (Děčín) and -0.36 (Liberec), meaning that the closer a location, that more often people visit it (see Appendix C).

The following findings were derived from the responses to the survey questions regarding the frequency and duration of the visit (Table 4, last column): even though Dresden's Loschwitz Elbe meadow had the largest number of visitors at the time of the interviews, the longest monthly visiting times were found in the Albertpark and Blüherpark. In Liberec, the largest number of visitors were in Přehrada Harcov and Park Budyšínská; yet the longest monthly visiting times were reported in Park Budyšínská and KunratickáSídliště. In Děčín, the largest numbers of visitors were in Mariánská louka and Kvádrberk, which also had the longest visiting times per month (Table 4). On average, the green spaces in the two Czech cities were used by respondents more intensively, namely, for 12 hours per month, than those in Dresden, which were used for 9 hours per month.

There was considerable variation in the distances travelled to reach the green spaces. Overall, about $45 \%$ of interviewees in all cities lived within $1 \mathrm{~km}$ of the green areas. Around three quarters lived within a $3 \mathrm{~km}$ radius to the green spaces; specifically, the proportions were $73 \%$ in Děčín and $78 \%$ in both Liberec and Dresden. At certain sites, a majority of visitors lived within $1 \mathrm{~km}$ : namely, $67 \%$ at Park Budyšínská (where $50 \%$ live within $500 \mathrm{~m}$ ) and $52 \%$ at Kunratická-Sídliště in Liberec, $70 \%$ at Beutlerpark and $50 \%$ at Blüherpark in Dresden and, finally, 60\% at Kvádrberk, 59\% at Park u Máchovky and 56\% at Stezka u Labe in Děčín.

The most frequently mentioned factors in need of improvement were (Table 5) a poor state of preservation or lack of facilities ( $29 \%$ of respondents, of which the largest proportion was in Dresden) and the state of maintenance of green areas (15\% of respondents, again with the largest proportion in Dresden). Other interviewees addressed the condition and usability of roads and pathways (15\%, with the largest proportion in Liberec, where there is often no access to water elements such as water reservoir), the quality or absence of water bodies and elements ( $12 \%$ of respondents, with the largest proportion in Liberec, where the water quality was criticised), littering and dog excrement (11\%) and the lack of sports and play facilities ( $9 \%$, with the largest proportion in Děćin). Other complaints more rarely expressed were unsafe feeling (criticised in Děčín) and a demand in both Czech cities for greater police presence.

Table 5. Complaints about disturbing factors.

\begin{tabular}{|c|c|c|c|c|}
\hline Frequency of Complaints & $\begin{array}{c}\text { Dresden } \\
(\%)\end{array}$ & $\begin{array}{c}\text { Liberec } \\
(\%)\end{array}$ & $\begin{array}{c}\text { Děčín } \\
(\%)\end{array}$ & $\begin{array}{c}\text { Weighted } \\
\text { Average }\end{array}$ \\
\hline Poor state of preservation or lack of facilities & 37.0 & 23.8 & 32.4 & 29.1 \\
\hline State or maintenance of green areas & 22.7 & 12.2 & 15.2 & 15.2 \\
\hline Condition and usability of roads and pathways & 9.2 & 21.2 & 8.1 & 14.9 \\
\hline Quality or absence of water bodies and elements & 5.0 & 17.4 & 8.6 & 12.2 \\
\hline Littering and dog excrement & 9.2 & 10.3 & 12.4 & 10.8 \\
\hline Poorly maintained or missing sports and play facilities & 5.9 & 7.7 & 11.4 & 8.6 \\
\hline Social interaction & 3.4 & 4.8 & 8.1 & 5.6 \\
\hline Design and art objects & 2.5 & 0.0 & 1.4 & 0.9 \\
\hline A lack of information & 1.7 & 0.3 & 0.5 & 0.6 \\
\hline Others (noise, surrounding, etc.) & 3.4 & 2.3 & 1.9 & 2.3 \\
\hline
\end{tabular}

Independently of the areas we met our respondents, they were asked for the most favoured green space of the entire city. Regarding the most favoured green spaces in Dresden, the most frequently given answers were the park Großer Garten (142 mentions) and the Elbe floodplain meadows (73 mentions); other frequently named green spaces were urban forests and well-known parks. Figure 3 shows all popular green spaces in Dresden that were mentioned at least three times.

The same question "What is your most preferred place in the city?" was also asked in Liberec and Děčín. Here, the named sites are shown in Figures 5 and 7. The most frequently mentioned green spaces in Liberec were the reservoir Přehrada Harcov and its surroundings ( 86 mentions), followed by Lidové sady and Park Budyšínská (73 and 
35 mentions, respectively) (Figure 5). The most popular areas in Děčín were Mariánská louka (83 mentions), Císařský výhled (73 mentions) and Pastýřská stěna (48 mentions) (Figure 7).

\subsection{General Appreciation of Green Space Types and Features}

In the survey, we asked for a general appreciation of 14 landscape types or their features in addition to the specific sites where the interviews took place. The highest rated landscape types were different in the three cities (Table 6): in Liberec, urban forests were preferred ( $56 \%$ of respondents) to public parks $(50 \%)$. This order was reversed in Dresden (public parks: 52\%, urban forests: $49 \%$ ) and Děčín (public parks: 57\%, urban forests: $55 \%)$. The same applies to rivers and streams, lakes, ponds and reservoirs, respectively. In Liberec, lakes, ponds and reservoirs were more popular (53\%) than rivers and streams (40\%), whereas in Dresden and Děčin, 48 and $43 \%$ of respondents, respectively, chose rivers and streams as the preferred landscape element types (those preferring lakes/ponds: 30 and $39 \%$, respectively). Regarding the types and features of green space with a medium popularity, it is noticeable that in Dresden, cemeteries, front gardens and allotments were rated more than twice as often as in the Czech cities, while playgrounds and sports facilities were mentioned about twice as frequently in Czechia as in Germany. In Liberec, fountains were much less preferred as green elements than in the other two cities by a factor of approximately four.

The chart in Figure 8 compares the level of appreciation of green space in the three cities. Based on these results, respective landscape elements can be identified for each city to help pinpoint potential forms of urban green space that are desired by the population and, thus, could boost the ecosystem service of recreation. Depending on the quality of each individual site, this does not lead to a map of actual services but rather the spatial potential for such an enhancement (see Figure 9 for a map of the different green elements and their appreciation in Dresden).

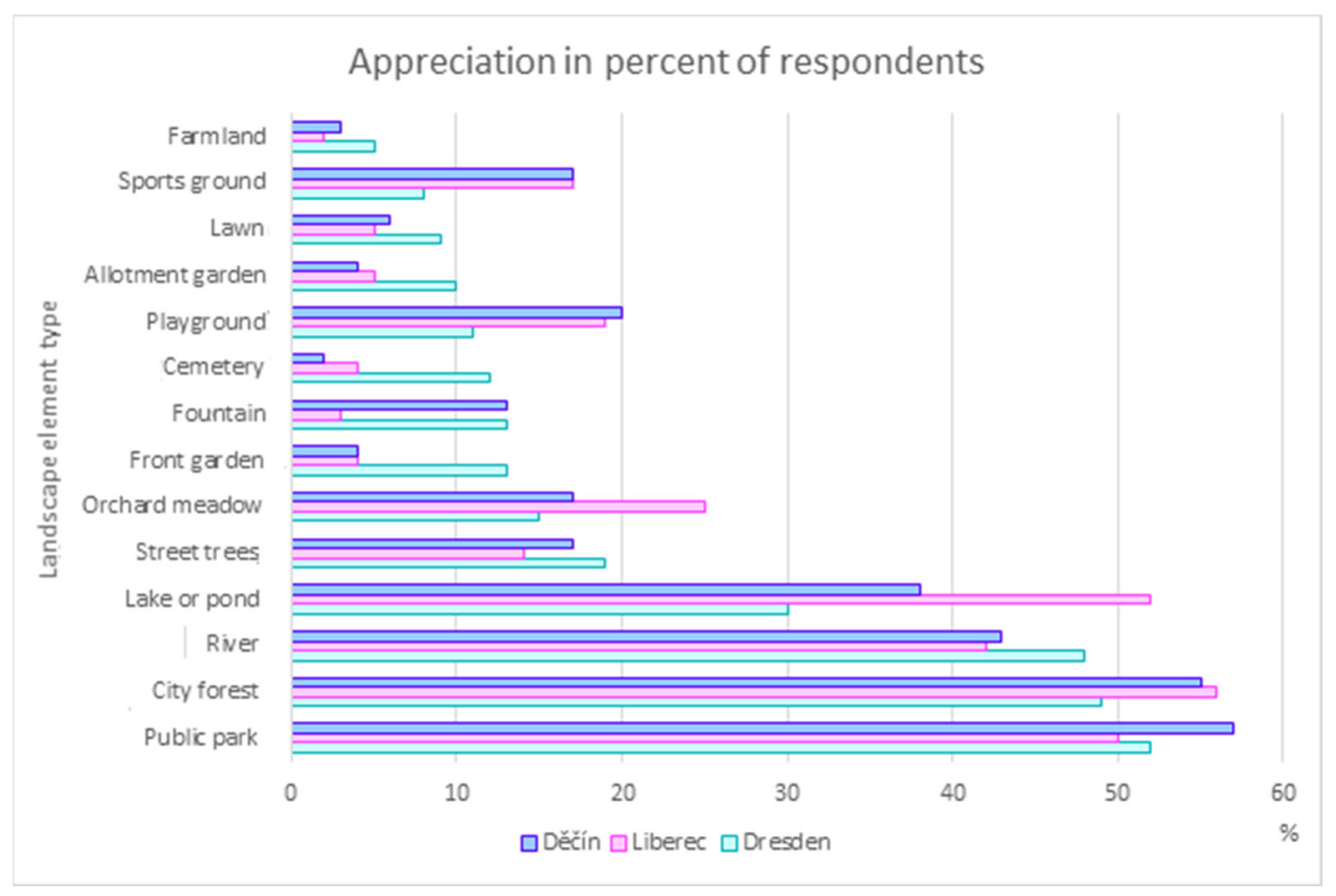

Figure 8. Landscape element types and their appreciation (Table 6) (source: authors' elaboration). 


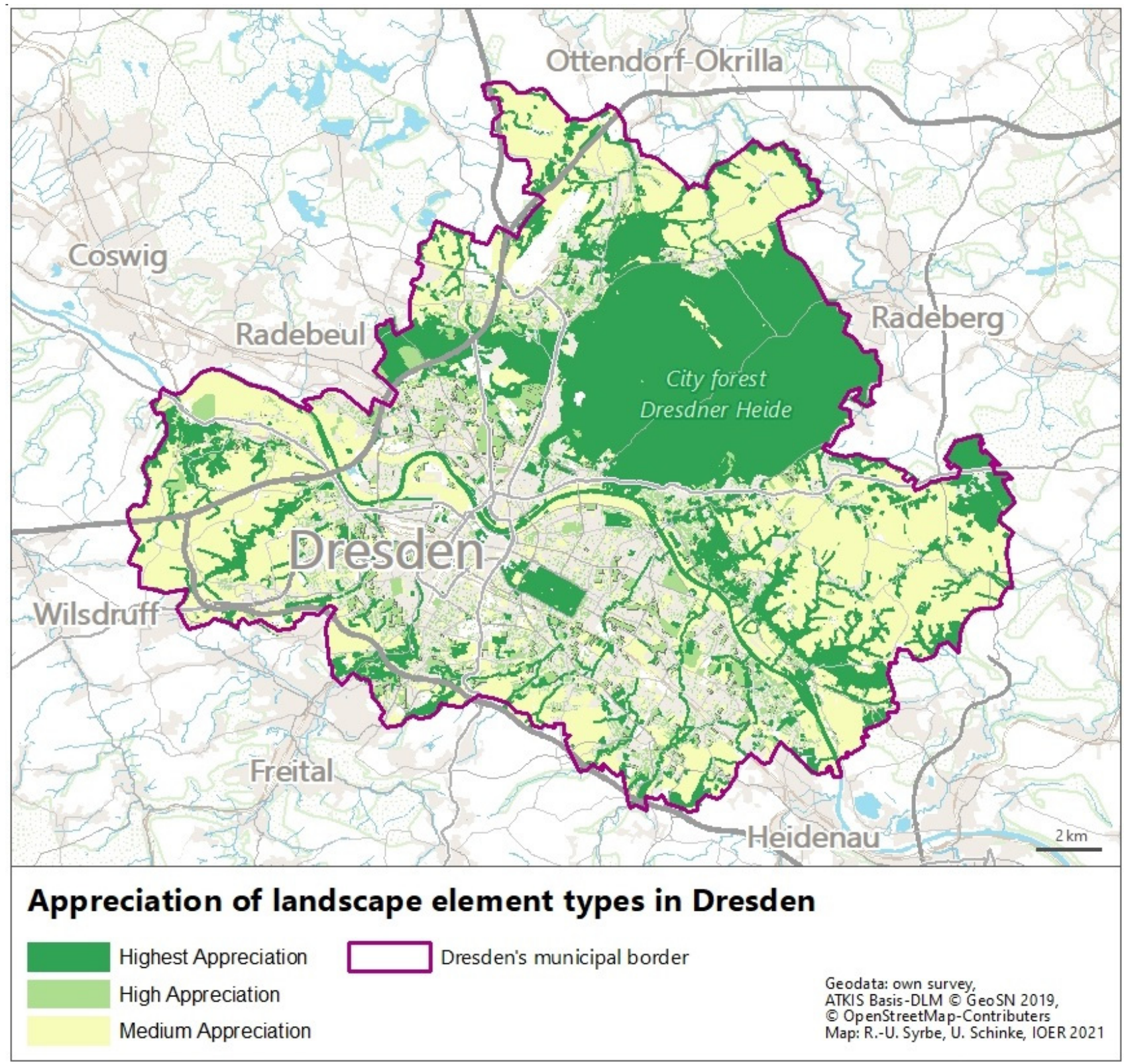

Figure 9. Map of preferred landscape elements in Dresden as potential areas to expand the recreational ecosystem service (source: authors' elaboration).

It was found that different age groups show somewhat divergent levels of appreciation of landscape elements. This can be illustrated in the case of Dresden. Here, public parks were the preferred form of landscape for $51.9 \%$ of respondents. Looking more closely, we note that this preference is stronger amongst the age groups $70-79$ years $(66.7 \%)$ and $>80$ years $(87.5 \%)$. In the group of middle-aged respondents, parks were slightly less appreciated. The second most popular landscape type, urban forest, was chosen by 114 of 235 respondents in Dresden (48\%). Here, the age group 18-59 years is strongly represented at over $50 \%$. The percentage for the group $18-29$ years is even higher at $51.2 \%$. The blue elements such as rivers, lakes, ponds and reservoirs are rated similarly by almost all age groups (48 and 30\%, respectively), although the preference decreases slightly with age. This trend is reversed in the case of street trees, street greenery and fountains, which were chosen by $37.5 \%$ of those aged $>80$. Only 36 of respondents $(15.3 \%)$ picked the meadow orchard as one of the three preferred landscape elements; this group includes no one aged $>80$. Front gardens are somewhat less preferred with 31 mentions $(13.2 \%)$, although around 
one third (29.4\%) of the under-18s attach great importance to front gardens. In general, playgrounds were only chosen by $11 \%$ of respondents, although this ratio includes $28 \%$ of young parents (aged 30 to 39 years). Lawns do not score very well (9.4\%); yet they are highly appreciated by $35.3 \%$ of the under-18s. Only $11.9 \%$ (28 out of 235 ) named cemeteries as the most important landscape element (and no one under 18 years of age); the preference for cemeteries, however, increases with age.

Table 6. Landscape elements and their appreciation (The colours relate to the three appreciation levels in Figure 9).

\begin{tabular}{lccc}
\hline Landscape Element & Dresden (\%) & Liberec (\%) & Děčín (\%) \\
\hline Public park & 52 & 50 & 57 \\
Urban forest & 49 & 56 & 55 \\
River or streams & 48 & 40 & 43 \\
Lake, pond or reservoir & 30 & 53 & 39 \\
Street trees and street greenery & 19 & 14 & 18 \\
Orchard meadow & 15 & 25 & 17 \\
Front garden at the house & 13 & 4 & 4 \\
Fountain & 13 & 3 & 14 \\
Cemetery & 12 & 5 & 2 \\
Playground & 11 & 18 & 20 \\
Allotment garden & 10 & 5 & 4 \\
Lawn & 9 & 5 & 6 \\
Public sport grounds & 8 & 18 & 16 \\
Agricultural area & 5 & 2 & 3 \\
\hline
\end{tabular}

\subsection{Health Effects and Ecosystem Services}

The results can be further differentiated by considering the health and well-being effects of the green space types. The interviewees were asked to tick one of five effects that the given 14 landscape element types generally have on them. People should decide whether a certain element type is relaxing (R), inspiring (I), boosting concentration (B), neutral $(\mathrm{N})$ or rather stressful $(\mathrm{S})$. Since there are five offered effects, we divided each number of ticks by the total times 5 , meaning that the value in Table 7 gives a relation of a chosen option against the theoretical mean if all five options were equally chosen (one fifth). That is, values above 1.0 say this effect is preferably ticked and below 1.0 means less. The last column in Table 7 gives the first letter of preferably chosen effect for each landscape element (bold letters) for Dresden in the order of preference; this dominant effect type (RI for relaxing and inspiring, RIN for relaxing, inspiring and neutral, etc.) is mapped in Figure 10. Although we could not add the effect types for the Czech cities and did not map all of them due to place limits, it is visible that the preference is very similar for all cities under study.

In the three cities, urban forest was most frequently named as the most important landscape element for relaxation (Table 7; Figure 10). Here, the ratios are $89 \%$ in Liberec, $85 \%$ in Dresden and 57\% in Děčín. Water bodies were also highly appreciated for relaxation in Dresden (84\%), Liberec (73\% rivers, 78\% lakes) and Děčín (53\% rivers, 55\% lakes). High values for inspiration were reported for fountains, water bodies, gardens and orchard meadows (highest in Liberec and somewhat lower in Děčín and Dresden). In contrast, cemeteries were named in the Czech cities as the most stressful form of green space, whereas in Dresden, children's playgrounds created most stress. Front gardens were much more neutral or negatively perceived in Czechia than in Germany. Table 8 gives a breakdown of the respondents' feelings about urban green elements in all three cities, which have been mapped for Dresden only (Figure 10). 
Table 7. Health effects of landscape element types as evaluated by respondents in Dresden (followed by the values for Liberec and Děčín); the figures in bold are the dominant types, the colours in last column refer to the health effects mapped in Figure 10.

\begin{tabular}{|c|c|c|c|c|c|c|}
\hline $\begin{array}{c}\text { Landscape } \\
\text { Element Type }\end{array}$ & Relaxing & Inspiring & $\begin{array}{l}\text { Boosts Con- } \\
\text { centration }\end{array}$ & Neutral & Stressful & $\begin{array}{l}\text { Dominant } \\
\text { (Dres- } \\
\text { den/Liberec/ } \\
\text { Děčín) }\end{array}$ \\
\hline Urban forest & 3.03 .02 .9 & 1.11 .21 .3 & 0.70 .40 .3 & 0.20 .30 .4 & 0.00 .00 .0 & RI/RI/RI \\
\hline River, stream & 2.92 .42 .7 & 1.31 .91 .6 & 0.80 .40 .4 & 0.10 .20 .3 & 0.00 .00 .0 & RI/RI/RI \\
\hline Lake, pond & 2.92 .62 .8 & 1.31 .81 .4 & 0.70 .40 .5 & 0.10 .20 .3 & 0.00 .00 .0 & RI/RI/RI \\
\hline Park & 2.72 .52 .6 & 1.31 .21 .3 & 0.50 .40 .5 & 0.40 .70 .5 & 0.00 .20 .1 & RI/RI/RI \\
\hline Fountain ${ }^{1}$ & 2.11 .72 .3 & 1.72 .01 .6 & 0.40 .30 .3 & 0.70 .90 .8 & 0.10 .10 .0 & $\mathrm{RI} / \mathrm{IR} / \mathrm{RI}$ \\
\hline $\begin{array}{c}\text { Street } \\
\text { tree/green }\end{array}$ & 2.40 .81 .9 & 1.10 .91 .9 & 0.40 .20 .3 & 1.02 .90 .8 & 0.00 .30 .1 & RIN/N/RI \\
\hline Front garden & 2.11 .21 .2 & 1.11 .81 .4 & 0.30 .20 .2 & 1.31 .62 .2 & 0.20 .10 .1 & RNI/INR/NIR \\
\hline $\begin{array}{l}\text { Orchard } \\
\text { meadow }\end{array}$ & 1.72 .32 .0 & 1.51 .81 .4 & 0.40 .30 .5 & 1.30 .71 .0 & 0.10 .00 .0 & RIN/RI/RIN \\
\hline $\begin{array}{l}\text { Allotment } \\
\text { garden }\end{array}$ & 1.31 .00 .9 & 1.20 .90 .9 & 0.30 .20 .2 & 1.72 .52 .7 & 0.40 .30 .3 & NRI/NR/N \\
\hline Cemetery & 1.50 .60 .5 & 0.50 .20 .1 & 0.40 .50 .2 & 2.22 .82 .5 & 0.41 .01 .6 & NR /NS/NS \\
\hline Lawn & 1.31 .51 .9 & 0.91 .51 .6 & 0.30 .30 .4 & 2.21 .51 .1 & 0.30 .10 .0 & NR/RIN/RIN \\
\hline Farmland & 1.10 .80 .6 & 0.70 .90 .5 & 0.20 .20 .2 & 2.92 .93 .5 & 0.10 .30 .2 & $\mathrm{NR} / \mathrm{N} /$ \\
\hline Playground & 0.50 .90 .9 & 1.21 .51 .3 & 0.30 .40 .6 & 2.31 .71 .7 & 0.80 .40 .6 & NI/NI/NI \\
\hline Sport ground & 0.20 .90 .6 & 1.22 .01 .7 & 0.50 .60 .6 & 2.61 .41 .8 & 0.50 .20 .3 & $\mathrm{NI} / \mathrm{IN} / \mathrm{NI}$ \\
\hline
\end{tabular}

${ }^{1}$ Element not mapped in Figure 10, since it is not included in basic data.

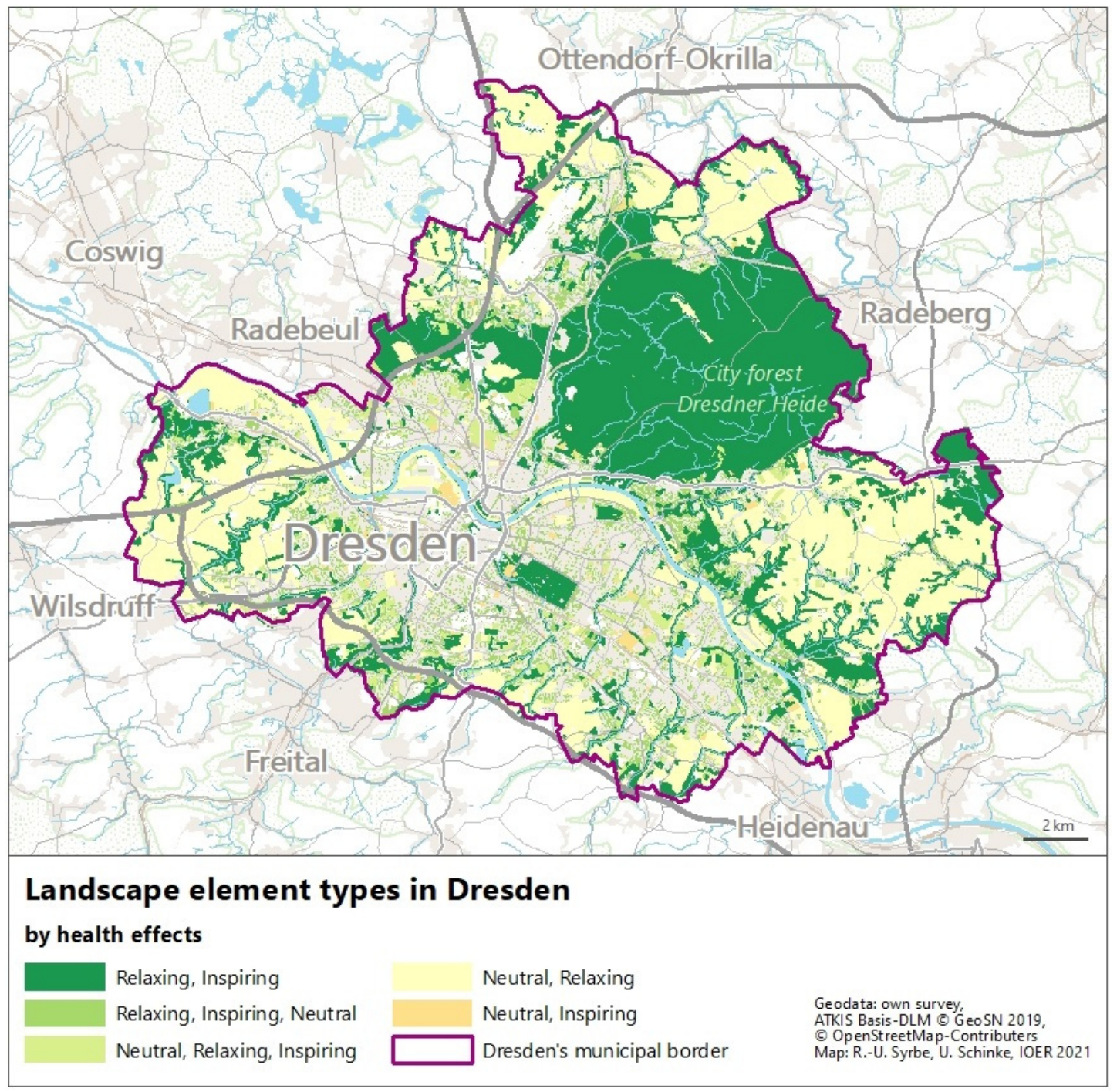

Figure 10. Landscape elements mapped by their health effects as a potential resource for recreation in Dresden (source: authors' elaboration). 
Table 8. Appreciation of selected urban ecosystem services (from 3: highly important to 1: unimportant).

\begin{tabular}{|c|c|c|c|c|c|}
\hline $\begin{array}{l}\text { Ecosystem Service Code/Group According to } \\
\text { CICES V5.1 }\end{array}$ & Issue Asked & Dresden & Liberec & Děčín & Average \\
\hline \multirow{4}{*}{$\begin{array}{l}\text { Cultural } \\
\text { 3.1.1.1-2 Physical and experiential interactions with } \\
\text { natural environment }\end{array}$} & $\begin{array}{l}\text { Possibility of } \\
\text { recreation }\end{array}$ & 3.0 & 2.9 & 2.9 & 2.9 \\
\hline & Social contacts & 2.4 & 2.4 & 2.5 & 2.4 \\
\hline & $\begin{array}{l}\text { Play, sports, leisure } \\
\text { activities }\end{array}$ & 2.5 & 2.5 & 2.3 & 2.5 \\
\hline & Dog walking & 1.6 & 1.9 & 1.9 & 1.8 \\
\hline $\begin{array}{l}\text { 3.1.2.1-4 Intellectual and representative interactions } \\
\text { with natural environment }\end{array}$ & $\begin{array}{l}\text { Inspiration for arts } \\
\text { and hobbies }\end{array}$ & 2.1 & 2.1 & 1.8 & 2.0 \\
\hline $\begin{array}{l}\text { 3.2.1.2 Spiritual, symbolic and other interactions } \\
\text { with nat. environment }\end{array}$ & $\begin{array}{l}\text { Spirituality and } \\
\text { religion }\end{array}$ & 1.6 & 1.6 & 1.4 & 1.6 \\
\hline \multirow{2}{*}{$\begin{array}{l}\text { 3.2.2.1-2 Other biotic characteristics that have a } \\
\text { non-use value }\end{array}$} & Habitat for plants & 2.9 & 2.9 & 2.9 & 2.9 \\
\hline & Habitat for animals & 2.9 & 2.8 & 2.9 & 2.9 \\
\hline \multirow{2}{*}{$\begin{array}{l}\text { Regulation: } \\
\text { 2.2.6.2 Atmospheric composition and conditions: } \\
\text { micro and regional climate regulation }\end{array}$} & $\begin{array}{l}\text { Improvement of the } \\
\text { micro-climate }\end{array}$ & 2.9 & 2.8 & 2.8 & 2.8 \\
\hline & $\begin{array}{l}\text { Improvement in air } \\
\text { quality }\end{array}$ & 3.0 & 2.9 & 2.9 & 2.9 \\
\hline $\begin{array}{l}\text { 2.2.6.1 Atmospheric composition and conditions: } \\
\text { global climate regulation }\end{array}$ & $\mathrm{CO}_{2}$ mitigation & 2.8 & 2.8 & 2.7 & 2.8 \\
\hline $\begin{array}{l}\text { 2.2.2.1 Lifecycle maintenance, habitat and gene pool } \\
\text { protection }\end{array}$ & $\begin{array}{l}\text { Habitat for bees } \\
\text { (pollination) }\end{array}$ & 2.9 & 2.8 & 2.8 & 2.8 \\
\hline $\begin{array}{l}\text { 2.2.1.3 Regulation of baseline flows } \\
\text { and extreme events }\end{array}$ & Flood protection & 2.6 & 2.7 & 2.7 & 2.7 \\
\hline
\end{tabular}

One of our other research goals was to investigate the importance of ES (named for the respondents as "benefits provided by urban green spaces"). Pre-defined benefits were presented to the respondents in simple language to aid their evaluation. Table 8 lists 13 urban ES and the terms asked for as well as the level of the respondents' appreciation, especially in the categories "highly important" and (negative) "unimportant" (Figure 11). The demand for some aspects differs from the social group or user characteristic. One example is that people having a dog mostly value the possibility of dog walking as important, while others see this as unimportant, which is significant in all three cities. In Dresden, only people with a dog valued this aspect, but $30 \%$ of people without one appreciated it as well, against $70 \%$ of people without a dog who did not. However, in both Czech cities, three times more people went with dogs and valued this aspect; additionally, more than a half of the people without a dog valued this aspect as important, too.

Since the demand is essential for the value of ecosystem services, it is likely that the same area of green spaces near the centre provides higher cultural services than that near the outskirts of the city. Thus, we analysed how the ecosystem services differed depending on the distance of the surveyed green areas to the centre (here represented by town hall, see Section 2). The correlation analysis for Dresden shows at 0.01 significance level relationships between certain ecosystem services, in particular recreation and all three issues of atmospheric regulation. However, there is only one slight correlation at 0.05 significance level between distance from city centre and the air quality improvement, i.e., the longer the distance, the higher the ES is valued. In Liberec, the air quality improvement is correlated with play, sports, leisure activities and global and local climate regulation, but there is no connection to the distance from the centre. The latter also applies to Děčín, where only the two aspects of climate regulation are significantly connected following the appreciation of respondents. 


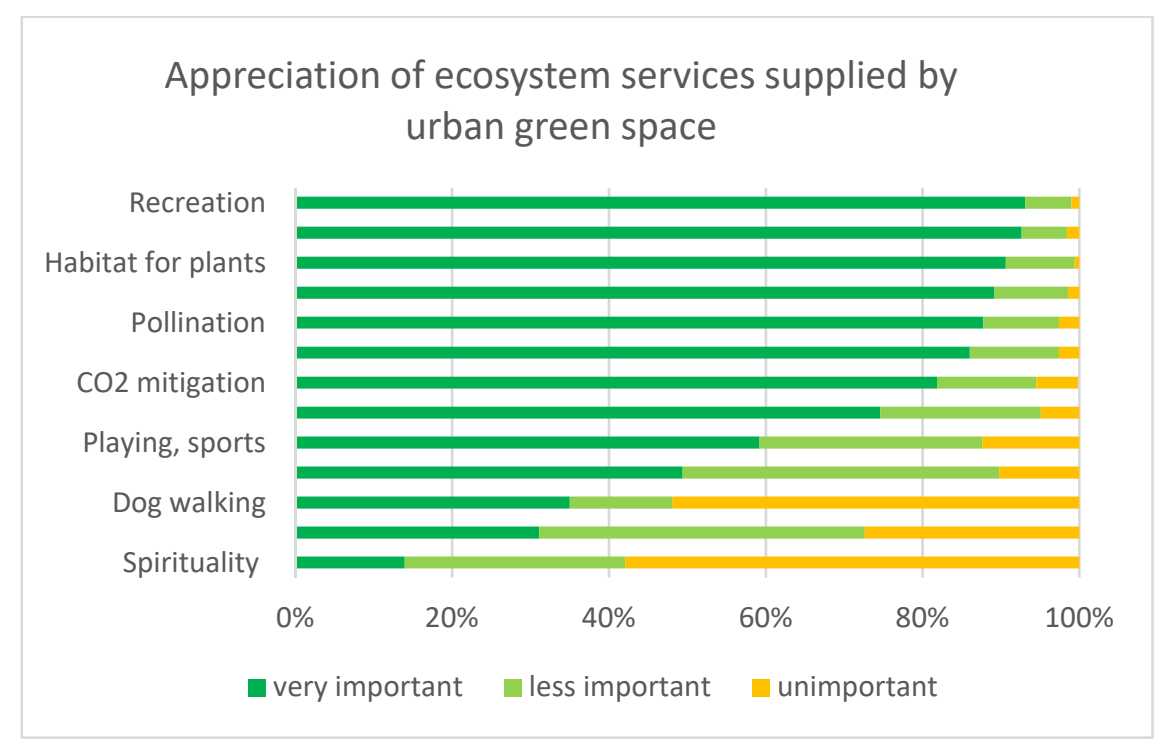

Figure 11. Appreciation of ecosystem services supplied by urban green space in the three cities (source: authors' elaboration).

\section{Discussion}

As we know from literature [12,46], urban nature significantly contributes to relaxation and physical recovery - particularly in the case of mental illnesses and stress-the greenery of our cities plays an important role in preventing modern diseases such as heart attack, stroke, arteriosclerosis, diseases of the musculoskeletal system as well as mental suffering. The majority of people we met in the urban green areas of our three study cities (i.e., between 52 and $74 \%$ ) felt well, recovered, peaceful, more relaxed, happier, physically better, energetic, better able to concentrate and more comfortable. This strongly supports the thesis that green space fosters physical/mental health and human well-being. Our surveys also confirmed positive social effects in the reduction in feelings of loneliness (between 46 and $61 \%$ of respondents in total or partial agreement) with only a very small minority complaining about bad social experiences (between 5 and $8 \%$ ) in urban green areas. Further, in regard to negative health effects or a lack of any such impact, under $1 \%$ were in full agreement, and $5 \%$ professed full or partial agreement. Therefore, the findings reveal as asked by the first research question that time spent in green surroundings indeed promotes positive thinking and social interaction, while helping to reduce stress. Additionally, the reported feelings are mostly unrelated to socio-demographic characteristics. No prevalent trend was identified across all three cities.

Table 4 also allows a comparison between the appreciation rating of individual areas and the length of stay. Green areas with the best (i.e., lowest) marks for satisfaction are by no means those in which visitors spend most time. For example, despite their top scores for satisfaction, Beutlerpark and Waldpark in Dresden, Liberecká výšina in Liberec and Stezka u Labe in Děčín were all visited for only brief periods by respondents. In fact, the length of time spent in a green space is more directly related to the size of the site and whether it functions merely as a connecting pathway. Moreover, the level of satisfaction with individual areas is not necessarily correlated with the frequency of usage. For instance, Přehrada Harcov got the worst mark for satisfaction in Liberec (see Table 4) even though it is the city's most preferred green area (Figures 4 and 5). An explanation could be that Přehrada Harcov is one of Liberec's largest green areas and, thus, possesses both positive and negative features. Specifically, the water reservoir and urban woodland are appreciated by locals despite some drawbacks such as poor water quality or the inferior catering on offer. This ability of visitors to differentiate between general benefits and particular drawbacks of green space enables the investigation of general preferences associated with green space types as well as the mapping of such preferences and, in particular, the health ES 
(Figures 9 and 10). The possibility for recreation (Figure 11) is one of the highest rated ecosystem services, followed by the improvement of air quality, indicating that the health effects of urban green are not just taken for granted but highly appreciated. Thus, the answer to our second research question is yes: people like to spend time in urban green areas, since they know about their health effects.

The most valued types of urban green space are urban forests, water bodies and parks. This aligns with [34], who found that water elements were the most preferred landscape elements, and with [36], who determined that people get a mental boost after spending just five minutes in a natural environment that features water bodies. Urban forests are generally higher valued than artificially designed parks. In particular, [37] claim that green space with a higher degree of naturalness is more conducive to good health; also, [35] found a relatively high positive impact of urban forest on human health. Depending on the quality of the area, Ref. [33] determined that urban parks are particularly valuable for families and, in particular, older people, who connect time spent in green surroundings with positive thinking such as the spirit of freedom, luck, happiness and reconciliation with nature; in contrast, younger people link visits to parks and other green spaces with the possibility of play and fitness, a finding that our study can confirm. Our results show that older respondents prefer parks (most responses in Dresden and Liberec), streams (most responses in Děčín) and lakes (Liberec) as well as playgrounds (surprisingly, only in Liberec). Middle-aged respondents prefer urban forests, rivers and parks; playgrounds are only named by parents in the age range 30-49 years. The youngest visitors (below 18) voted mostly for parks, rivers and, surprisingly, orchard meadows. These selective preferences are an answer to our third research question and suggest a need for the sensible management of diverse green space types and their interconnection in the form of an integrated system of green urban infrastructure.

A lack of physical activity and the absence of environmental stimuli in urban life have negative effects on public health [44]. Well-known obstacles to the use of green space are many families' lack of time as well as little motivation to get enough exercise after work or the lack of green cycle pathways to encourage people to get on their bicycles. Nearly half of the people questioned in our study mainly visit urban green areas in a $1 \mathrm{~km}$ radius from their homes; moreover, three quarters use green spaces within a $3 \mathrm{~km}$ radius. Small green areas are visited by nearby residents, whereas the most popular parks and urban forests are frequented by residents from all around the city. In particular, small green areas are especially important if located in the local neighbourhood, cf. research question four. At the same time, attractive green spaces can motivate people to walk there despite urgent everyday business, thereby greatly benefiting their health $[25,26]$. For instance, the most popular green areas in Dresden were mentioned as preferred sites by 142 (Großer Garten) and 74 (Elbe meadows), respectively of the 235 respondents; indeed, the latter was visited by those living more than $10 \mathrm{~km}$ away.

A large proportion of urban green space in Dresden is made up of allotment gardens (the yellow-green-coloured areas in Figure 10). However, this form of green space elicits a range of views: $31.5 \%$ of respondents consider it relaxing, while for $10.2 \%$, allotments are a source of stress. Ref. [52] have proposed developing community gardens, using the example of Golgi park in the north of Dresden to show how this type of green space is able to combine several positive effects such as access to fresh air and green surroundings with meaningful work, social encounters, a supply of fresh fruit and tasty vegetables as well as the opportunity for children to experience and play unrestrictedly in urban nature. This proposal is certainly a good way of creating garden areas in the modern city.

While the products of provisioning ES can be transported into cities, regulating and cultural ES generally have to be supplied close to or even within cities. The respondents to our survey spend their leisure time in urban green because they know that this improves their health. The most popular ecosystem services in our three cities were the possibility of recreation and better air quality (93\% of the respondents in both cases), which are the two most important aids to good health. However, the next most valued ES were urban 
nature as providing habitats for plants, animals and, in particular, bees (respectively, for all cities: 90, 89 and 88\%), which promote a sense of well-being (and, thus, also mental health). This is in line with [53], who found that "bird species richness is positively related to lifesatisfaction across Europe, with a comparable effect to income". The third most valued ES was microclimate regulation (86\%), while all other benefits such as flood protection $(75 \%)$ were lower in popularity. Green spaces were not particularly valued as sources of religious or spiritual inspiration, while activities such as dog walking were more often named as unimportant than important (the latter almost exclusively by the people with dog).

We are aware of some limitations due to the study design that could not provide information on all thinkable aspects such as the data on visiting time and proximity from residence to green were self-reported. Further, there are divergences between residents of the three cities regarding the particular evaluations of green space and mix of named benefits. For example, the interpretation/perception of "stimulating" and "relaxing" is different in Germany and Czechia. Other disparities are the greater prevalence of complaints about social aspects in Czechia than Germany, the spiritual-religious value that was least valued in Czech cities and the critical perception of children's playgrounds in Germany. Yet such differences are possibly due to the diverse facilities or surroundings in the three cities. For example, Liberec has a great deal of forest both within and around the city precincts as well as a popular water reservoir. Dresden and Děčín, in turn, have the Elbe as a prominent river and major transport route, compared to the much smaller rivers in Liberec (Nisa).

\section{Conclusions}

In general, the results show the high valuation and appreciation of urban green space for self-reported well-being and mental health, confirming a positive beneficial impact on physical health, as it is perceived by the people who use urban green spaces. Time spent in urban green space helps them to relax, enhances their well-being and enables rest and recuperation, while refreshing and promoting social contacts. The majority of asked individuals feel more relaxed, happier, physically better and more energetic after visiting an urban green, indicating not just improved health but also providing evidence of the welfare effects of urban green. Near-natural (i.e., less intensively maintained) green space with safe, clean and accessible pathways as well as water bodies is the most preferred type. Frequent maintenance measures are viewed rather critically. In addition, we found some specific differences in the appreciation of other forms of green spaces depending on the country and city.

It is particularly important if urban green is in close proximity to residential areas: nearby green spaces are more frequently visited than those further away. At the same time, distant green spaces, which are very well known and offer diverse features, may also be preferred. However, the length of stay and frequency of visits are not directly related to the level of appreciation, but rather to the location, size and facilities of green spaces as well as the aim of the visit, i.e., for some specific purpose (relaxation, fitness, etc.) or merely as a pathway to somewhere else.

The most popular types of green space are urban forests, public parks and water bodies. The local inhabitants we surveyed particularly liked those green elements that are characteristic of their city, i.e., they seem to prefer precisely those types of urban nature that are particularly typical and well developed. However, wide-ranging criticisms also highlight certain shortcomings such as a lack of road connections, poor access to water or a lack of suitable facilities. Further, the repair of broken equipment could significantly improve the urban quality of life. The appreciation of urban green varies depending on the age or typical habits of residents. Thus, public parks are particularly important to the elderly as well as (to a lesser extent) young people and families. For middle-aged individuals, urban forests are the most popular form of green space. Water bodies are highly rated by almost all age groups, with a slight drop in appreciation by the elderly. On the other hand, older people, who may be unable to travel to more distant parks or 
forests, enjoy street trees, street greenery and fountains. Young parents appreciate the availability of playgrounds and complain when such play or sports facilities are lacking.

Regarding urban ecosystem services, visitors to green spaces particularly value the recreational opportunities, aesthetic qualities, climate regulatory function and high biodiversity they offer. The majority of visitors view the flood protection services of urban greenery as important along with its various functions as a carbon sink and a place for sports, games and social contacts.

From our study presented in this article, we derive specific recommendations for the decision makers of each city that are stated on national languages in the Supplementary Materials: Generally, we suggest that city planners and managers should reduce the efforts to maintain artificial green areas (planting, mowing, cleaning and tidying up) in favour of a greater degree of naturalness, thereby providing habitats for plants and animals, as well as ensuring access to water bodies. Since designed and artificial elements (such as fountains) are less appreciated by visitors of urban green, more should be spent on providing litter bins and benches, diverse forms of relief and vegetative structures as well as places that encourage positive social interaction. In certain locations regarded as unsafe by locals, meeting places should be specially protected by the police or security personnel. The second paragraph of conclusions implies that urban green infrastructure should be interconnected to establish an integrated system of diverse green spaces with different levels of maintenance. The possible visitors of urban green should have some green area within a $1 \mathrm{~km}$ radius to their home; in addition, it is strongly recommended that a larger park or other extensive green area be located within a $3 \mathrm{~km}$ radius. Regarding the third paragraph of conclusions, we recommend that sports and play facilities should be integrated into parks and urban forests instead of developing these as separate sites only used by a small group of people. The appreciation of urban green spaces can also be considerably boosted by the provision of good quality snack bars or cafes. Urban planners and politicians are strongly urged to enhance and connect green space in their cities rather than develop these most valuable areas for residential, commercial or transport purposes.

Supplementary Materials: The following materials are available online at http:/ /bidelin.ioer.eu/ ergebnisse/ (in German and Czech, respectively): The two cited project booklets (for Dresden and Liberec), Study of ES in Děčín, Research report on assessment of selected ES in Liberec and Děčín, Recommendations for an application of the ES concept in practice, Description of the project, Project flyer, Press releases, Documentation of several conferences and events, Science pathways, Video on the benefits of urban nature.

Author Contributions: Conceptualization K.G., J.L., O.B., R.-U.S. and J.M.; methodology, R.-U.S., K.G., I.N., J.L., J.M., P.B. and J.B.; validation, I.N., J.L., J.M., P.B., L.D., P.M. and J.B.; formal analysis, I.N. and J.L.; investigation, I.N., P.B., R.-U.S., K.G., J.L., L.D., J.M., B.K. and J.B.; data curation, I.N. and P.B.; writing—original draft preparation, R.-U.S. and I.N.; writing—review and editing, R.-U.S., K.G., I.N., J.L., P.B., L.D., O.B., J.M. and J.B.; visualization, R.-U.S., I.N., J.L., L.D. and P.M.; project administration, K.G. and J.L.; funding acquisition, K.G., R.-U.S. and J.L. All authors have read and agreed to the published version of the manuscript.

Funding: This research was funded by EU project BIDELIN “The values of ecosystem services, biodiversity and green-blue infrastructure in cities using the examples of Dresden, Liberec and Děčín" in the framework of the Interreg V-A 2014-2020 Saxony-Czech Republic initiative "Hallo Nachbar-Ahoj sousede" of the European fund for regional development managed by the Sächsische Aufbaubank, Grant No. 100282320 and co-financed by the project "Smart City—Smart Region-Smart Community" by the Operational Programme Research, Development and Education of the Czech Republic_Grant No. CZ.02.1.01/0.0/0.0/17_048/0007435.

Institutional Review Board Statement: Not applicable.

Informed Consent Statement: Informed consent was obtained from all subjects involved in the study.

Data Availability Statement: Data on statistics is contained within the article and Appendix C. Answer data to the questionnaire (Appendix B) is available on request due to restrictions of data privacy. 
Acknowledgments: Our special thanks go to the numerous student assistants in Germany and the Czech Republic who helped us with the surveys, and of course to all the citizens in Dresden, Liberec and Děčín who took their time and made the effort to patiently answer our questions. Many thanks for assistance with the layout of the maps and illustrations to Sabine Witschas and Ulrike Schinke and to Derek Henderson for the language polishing of the manuscript.

Conflicts of Interest: The authors declare no conflict of interest.

\section{Appendix A}

Extended description of the study sites.

\section{Appendix B}

Questionnaire, translated into English (from German/Czech original).

\section{Appendix C}

Additional statistical analyses.

\section{References}

1. United Nations Dept. of Economic and Social Affairs. World Urbanization Prospects. The 2018 Revision. New York, 126p. Available online: https:/ / population.un.org/wup/Publications/Files/WUP2018-Report.pdf (accessed on 23 January 2020).

2. Statista. Europäische Union: Urbanisierungsgrad in den Mitgliedsstaaten im Jahr 2018. Available online: https:/ / de.statista.com/ statistik/daten/studie/249029/umfrage/urbanisierung-in-den-eu-laendern/ (accessed on 25 November 2020).

3. Grunewald, K.; Li, J.; Xie, G.; Kümper-Schlake, L. Towards Green Cities: Urban Biodiversity and Ecosystem Services in China and Germany. 2017. Available online: https:/ / www.springer.com/gp/book/9783319582221 (accessed on 15 March 2021).

4. European Commission. Biodiversity Strategy for 2030 Bringing Nature Back into Our Lives; European Commission: Brussels, Belgium, 2020; 23p.

5. United Nations Dept. of Economic and Social Affairs. Transforming our world: The 2030 Agenda for Sustainable Development. 2015. Available online: https://sustainabledevelopment.un.org/post2015/transformingourworld (accessed on 19 February 2021).

6. German Federal Government. German Sustainable Development Strategy 2018 Update. 60p. Available online: https://www. bundesregierung.de/resource/blob/975274/1588964/1b24acbed2b731744c2ffa4ca9f3a6fc/2019-03-13-dns-aktualisierung-20 18-englisch-data.pdf?download=1 (accessed on 25 November 2020).

7. TEEB DE. Natural Capital Germany. Ecosystem Services in the City-Protecting Health and Improving Quality of Life; Kowarik, I., Bartz, R., Brenck, M., Eds.; In German: Naturkapital Deutschland. Ökosystemleistungen in der Stadt-Gesundheit schützen und Lebensqualität erhöhen; Technical University Berlin, Helmholtz-Centre for Environmental Research-UFZ: Leipzig-Halle, Germany, 2016; Volume 2016.

8. Bastian, O.; Cudlín, P.; Pechanec, V.; Brzoska, P.; Štěrbová, L.; Včeláková, R.; Purkyt, J.; Grunewald, K. Assessments of Biodiversity and Habitat Services in Cities-Exemplified by Dresden (Germany) and Liberec (Czech Republic). Ekológia 2020, 39, 174-189. [CrossRef]

9. European Commission. Guidance on a Strategic Framework for Further Supporting the Development of EU-Level Green and blue Infrastructure. 2019. 102p. Available online: https:/ / ec.europa.eu/transparency/regdoc/rep/10102/2019/EN/SWD-2019-1 93-F1-EN-MAIN-PART-1.PDF (accessed on 25 November 2020).

10. Syrbe, R.-U.; Chang, J.; Hu, T. Options to increase green spaces and biodiversity in cities. In Towards Green Cities: Urban Biodiversity and Ecosystem Services in China and Germany; Grunewald, K., Li, J., Xie, G., Kümper-Schlake, L., Eds.; Springer Int. Publishing: Cham, Switzerland, 2017; pp. 119-131.

11. Engemann, K.; Pedersen, C.B.; Arge, L.; Tsirogiannis, C.; Mortensen, P.B.; Svenning, J.-C. Residential green space in childhood is associated with lower risk of psychiatric disorders from adolescence into adulthood. Proc. Natl. Acad. Sci. USA 2019, 116, 5188-5193. [CrossRef]

12. Thompson, C.W.; Aspinall, P.; Roe, J. Access to Green Space in Disadvantaged Urban Communities: Evidence of Salutogenic Effects Based on Biomarker and Self-report Measures of Wellbeing. Proc. Soc. Behav. Sci. 2014, 153, 10-22. [CrossRef]

13. Krekel, C.; Kolbe, J.; Wwstemann, H.; Wüstemann, H. The Greener, the Happier? The Effects of Urban Green and Abandoned Areas on Residential Well-Being. SSRN Electron. J. 2015, 121, 117-121. [CrossRef]

14. Wüstemann, H.; Zhang, Y. Well-being and health effects of urban green space. In Towards Green Cities-Urban Biodiversity and Ecosystem Services in China and Germany; Grunewald, K., Li, J., Xie, G., Kümper-Schlake, L., Eds.; Springer Int. Publishing: Cham, Switzerland, 2017; pp. 44-48.

15. Korpela, K.; Kyttä, M.; Hartig, T. Restorative Experience, Self-Regulation, and Children's Place Preferences. J. Environ. Psychol. 2002, 22, 387-398. [CrossRef]

16. Kuo, F.E.; Sullivan, W.C. Aggression and Violence in the Inner City. Environ. Behav. 2001, 33, 543-571. [CrossRef] 
17. Thompson, C.W.; Roe, J.; Aspinall, P.; Mitchell, R.; Clow, A.; Miller, D. More green space is linked to less stress in deprived communities: Evidence from salivary cortisol patterns. Landsc. Urban Plan. 2012, 105, 221-229. [CrossRef]

18. Maas, J.; Verheij, R.A.; Groenewegen, P.P.; de Vries, S.; Spreeuwenberg, P. Green space, urbanity, and health: How strong is the relation? J. Epidemiol. Community Health 2006, 60, 587-592. [CrossRef] [PubMed]

19. Brindley, P.; Cameron, R.W.; Ersoy, E.; Jorgensen, A.; Maheswaran, R. Is more always better? Exploring field survey and social media indicators of quality of urban greenspace, in relation to health. Urban For. Urban Green. 2019, 39, 45-54. [CrossRef]

20. Astell-Burt, T.; Feng, X. Does sleep grow on trees? A longitudinal study to investigate potential prevention of insufficient sleep with different types of urban green space. SSM Popul. Health 2020, 10, 100497. [CrossRef]

21. Van den Bosch, M.; Ode Sang, A. Urban natural environments as nature-based solutions for improved public health-A systematic review of reviews. Environ. Res. 2017, 158, 373-384. [CrossRef] [PubMed]

22. Li, Q. Forest Medicine (Public Health in the 21st Century); Nova Science Publishers Inc.: Hauppauge, NY, USA, 2018.

23. Caperna, A.; Serafini, S. Biourbanism as new epistemological perspective between Science, Design and Nature. In Architecture $\mathcal{E}$ Sustainability: Critical Perspectives. "Generating Sustainability Concepts from an Architectural Perspective"; KU Leuven-Faculty of Engineering: Brussels/Ghent, Belgium, 2015.

24. Ulrich, R.S. View through a Window May Influence Recovery from Surgery. Science 1984, 224, 420-421. [CrossRef]

25. Bowler, D.E.; Buyung-Ali, L.M.; Knight, T.M.; Pullin, A.S. A systematic review of evidence for the added benefits to health of exposure to natural environments. BMC Public Health 2010, 10, 456. [CrossRef]

26. De Vries, S.; van Dillen, S.M.; Groenewegen, P.P.; Spreeuwenberg, P. Streetscape greenery and health: Stress, social cohesion and physical activity as mediators. Soc. Sci. Med. 2013, 94, 26-33. [CrossRef] [PubMed]

27. Statistisches Bundesamt. Cardiovascular Diseases Cause the Highest Medical Costs in Germany. [in German: Herz-KreislaufErkrankungen verursachen die höchsten Krankheitskosten in Deutschland] (Press release Nov. 2011). Available online: https:/ / www.destatis.de/DE/Presse/Pressemitteilungen/2017/09/PD17_347_236.html (accessed on 24 March 2021).

28. Grunewald, K.; Richter, B.; Meinel, G.; Herold, H.; Syrbe, R.-U. Proposal of indicators regarding the provision and accessibility of green spaces for assessing the ecosystem service "recreation in the city" in Germany. Int. J. Biodivers. Sci. Ecosyst. Serv. Manag. 2017, 13, 26-39. [CrossRef]

29. Kleinschroth, F.; Kowarik, I. COVID-19 crisis demonstrates the urgent need for urban greenspaces. Front. Ecol. Environ. 2020, 18, 318-319. [CrossRef]

30. Venter, Z.S.; Barton, D.N.; Gundersen, V.; Figari, H.; Nowell, M. Urban nature in a time of crisis: Recreational use of green space increases during the COVID-19 outbreak in Oslo, Norway. Environ. Res. Lett. 2020, 15, 104075. [CrossRef]

31. World Health Organization. COVID-19 Disrupting Mental Health Services in Most Countries, WHO Survey. 2020. Available online: https:/ / www.who.int/news/item/05-10-2020-covid-19-disrupting-mental-health-services-in-most-countries-whosurvey (accessed on 26 November 2020).

32. Bauer, N.; Martens, D. The Meaning of Landscape for Human Health-Results of Most Recent WSL Research [in German: Die Bedeutung der Landschaft für die menschliche Gesundheit—Ergebnisse neuester Untersuchungen der WSL]: Forum für Wissen, Volume 2010; pp. 43-51. Available online: https://www.wsl.ch/de/ueber-die-wsl/veranstaltungen-und-besuche-an-der-wsl/ forum-fuer-wissen.html (accessed on 15 March 2021).

33. Chiesura, A. The role of urban parks for the sustainable city. Landsc. Urban Plan. 2004, 68, 129-138. [CrossRef]

34. Dramstad, W.; Tveit, M.S.; Fjellstad, W.; Fry, G. Relationships between visual landscape preferences and map-based indicators of landscape structure. Landsc. Urban Plan. 2006, 78, 465-474. [CrossRef]

35. Hansmann, R.; Hug, S.-M.; Seeland, K. Restoration and stress relief through physical activities in forests and parks. Urban For. Urban Green. 2007, 6, 213-225. [CrossRef]

36. Barton, J.; Pretty, J. What is the Best Dose of Nature and Green Exercise für Improving Mental Health? A Multi-Study Analysis. Environ. Sci. 2010, 44, 3947-3955. [CrossRef] [PubMed]

37. Roe, J.; Aspinal, P. The restorative benefits of walking in urban and rural settings in adults with good and poor mental health. Health Place 2011, 17, 103-113. [CrossRef] [PubMed]

38. Arvay, C.G. Biophilia in the City: How Do We Bring the Heath Power of Nature into Our Cities; In German: Biophilia in der Stadt: Wie wir die Heilkraft der Natur in unsere Städte bringen; Goldmann Publishers: Munich, Germany, 2018; 351p.

39. German Federal Ministry for the Environment, Nature Conservation and Nuclear Safety. Nature Appreciation 2017-Residents' Survey on Nature and Biological Diversity [in German: Naturbewusstsein 2017- Bevölkerungsumfrage zu Natur und biologischer Vielfalt] Volume 70p. Available online: https://www.bfn.de/themen/biologische-vielfalt/nationale-strategie/projekt-desmonats/naturbewusstsein-2017.html (accessed on 15 March 2021).

40. Grunewald, K.; Bastian, O.; Brzoska, P.; Kochan, B.; Neumann, I.; Syrbe, R.-U. The Nature in the City of Dresden: What It Serves and How It Protects; In German: Natur in der Stadt Dresden: Was sie Leistet, wie sie Nützt; IÖR: Dresden, Germany, 2020; 48p.

41. Kowarik, I. Wilderness in Urban Areas. Characteristics, Chances and Challenges. [in German: Wildnis in urbanen Räumen. Erscheinungsformen, Chancen und Herausforderungen]. Nat. Landsch. 2015, 90, 470-474.

42. Seiwert, A.; Rößler, S. Understanding the term green infrastructure: Origins, rationales, semantic content and purposes as well as its relevance for application in spatial planning. Land Use Policy 2020, 97, 104785. [CrossRef]

43. Thompson, C.W. Linking landscape and health: The recurring theme. Landsc. Urban Plan. 2011, 99, 187-195. [CrossRef] 
44. Bratmann, G.N.; Hamilton, J.P.; Hahn, K.S.; Daily, G.C.; Gross, J.J. Nature Experience Reduces Rumination and Subgenus Prefrontal Cortex Activation. Proc. Natl. Acad. Sci. USA 2015, 112, 8567-8572. [CrossRef]

45. $\mathrm{Hu}, \mathrm{T}$;; Chang, J.; Syrbe, R.-U. Green Infrastructure Planning in Germany and China. A comparative approach to green space policy and planning structure. In Inclusive Urbanism. Advances in Research, Education and Practice; Wende, W., Nijhuis, S., Mensing-de Jong, A., Humann, M., Eds.; Research in Urbanism Series; TU Delft, OPEN.: Delft, The Netherlands, 2020; Volume 6, pp. 99-125.

46. Maas, J.; Verheij, R.A.; De Vries, S.; Spreeuwenberg, P.; Schellevis, F.G.; Groenewegen, P.P. Morbidity is related to a green living environment. J. Epidemiol. Community Health 2009, 63, 967-973. [CrossRef]

47. Kistemann, T.; Völker, S.; Lengen, C. City Blue—The Health Meaning of Water Bodies in the Urban Area; In German: Stadtblau-Die gesundheitliche Bedeutung von Gewässern im urbanen Raum; Natur-und Umweltschutz Akademie NRW (NUA): Recklinghausen, Germany, 2010; Volume 2010, pp. 61-66.

48. Van Dyck, D.; Cardon, G.; Deforche, B.; Sallis, J.F.; Owen, N.; De Bourdenaudhuij, I. Neighbourhood SES and walkability are related to physical activity behaviour in Belgian adults. Prev. Med. 2010, 50, S74-S79. [CrossRef]

49. Bevölkerungsbestand. Landeshauptstadt Dresden. Available online: https://www.dresden.de/de/leben/stadtportrait/statistik/ bevoelkerung-gebiet/Bevoelkerungsbestand.php (accessed on 11 March 2021).

50. Český Statistický Úřad. Available online: https://www.czso.cz/csu/czso/statistiky (accessed on 11 March 2021).

51. Louda, J.; Dubova, L.; Hrbková, K.; Meyer, P.; Prošková, R.; Pudil, M.; Jand'ourek, J.; Cudlín, P. Urban Nature in Liberec-What It Provides Us and What It Benefits. [In Czech: Městská příroda v Liberci: Co nám přináší a co potřebuje] University Jana Evangelisty Purkyně v Ústí nad Labem in cooperation with the city council of Liberec. Available online: http:/ / www.ieep.cz/ mestska-priroda-v-liberci-co-nam-prinasi-a-co-potrebuje/ (accessed on 15 February 2021).

52. Aguiar Pedro, A.; Görner, A.; Lindner, A.; Wende, W. More than fruits and vegetables. Community garden experiences from the Global North to foster green development of informal areas in Sao Paulo, Brazil. In Inclusive Urbanism-Advances in Research, Education and Practice; Wende, W., Nijhuis, S., Mensindde Jong, A., Humann, M., Eds.; TU Delft, OPEN.: Delft, The Netherlands, 2020; pp. 219-241.

53. Methorst, J.; Rehdanz, K.; Mueller, T.; Hansjürgens, B.; Bonn, A.; Böhning-Gaese, K. The importance of species diversity for human well-being in Europe. Ecol. Econ. 2021, 181, 106917. [CrossRef] 